\title{
Eolian dust input to the Subarctic North Pacific
}

\author{
Sascha Serno ${ }^{\mathrm{a}, \mathrm{b}, *}$, Gisela Winckler ${ }^{\mathrm{a}, \mathrm{c}}$, Robert F. Anderson ${ }^{\mathrm{a}, \mathrm{c}}$, Christopher T. Hayes ${ }^{\mathrm{a}, \mathrm{c}}$, \\ David McGee $^{\mathrm{d}}$, Björn Machalett ${ }^{\mathrm{e}, \mathrm{f}}$, Haojia Ren ${ }^{\mathrm{a}}$, Susanne M. Straub ${ }^{\mathrm{a}}$, Rainer Gersonde ${ }^{\mathrm{g}}$, \\ Gerald H. Haug ${ }^{\text {h }}$ \\ a Lamont-Doherty Earth Observatory of Columbia University, 61 Route 9W, Palisades, NY 10964, USA \\ b DFG-Leibniz Center for Surface Process and Climate Studies, Institute of Earth and Environmental Science, University of Potsdam, Karl-Liebknecht-Straße 24, \\ D-14476 Potsdam-Golm, Germany \\ ${ }^{\mathrm{c}}$ Department of Earth and Environmental Sciences, Columbia University, New York, NY 10027, USA \\ d Department of Earth, Atmospheric and Planetary Sciences, Massachusetts Institute of Technology, Cambridge, MA 02139, USA \\ e Institute of Geography, Climatology Group, Humboldt-Universität zu Berlin, Unter den Linden 6, D-10099 Berlin, Germany \\ ${ }^{\mathrm{f}}$ Department of Natural and Applied Sciences, Bentley University, 175 Forest Street, Waltham, MA 02452, USA \\ g Alfred Wegener Institute for Polar and Marine Research, Columbusstraße, D-27568 Bremerhaven, Germany \\ ${ }^{\mathrm{h}}$ Geological Institute, ETH Zürich, Sonneggstrasse 5, 8092 Zürich, Switzerland
}

\section{A R T I C L E I N F O}

\section{Article history:}

Received 12 April 2013

Received in revised form 5 November 2013

Accepted 11 November 2013

Available online 24 December 2013

Editor: G.M. Henderson

\section{Keywords:}

eolian dust

Subarctic North Pacific

INOPEX

helium-4

Th-232

REE

\begin{abstract}
A B S T R A C T
Eolian dust is a significant source of iron and other nutrients that are essential for the health of marine ecosystems and potentially a controlling factor of the high nutrient-low chlorophyll status of the Subarctic North Pacific. We map the spatial distribution of dust input using three different geochemical tracers of eolian dust, ${ }^{4} \mathrm{He},{ }^{232} \mathrm{Th}$ and rare earth elements, in combination with grain size distribution data, from a set of core-top sediments covering the entire Subarctic North Pacific. Using the suite of geochemical proxies to fingerprint different lithogenic components, we deconvolve eolian dust input from other lithogenic inputs such as volcanic ash, ice-rafted debris, riverine and hemipelagic input. While the open ocean sites far away from the volcanic arcs are dominantly composed of pure eolian dust, lithogenic components other than eolian dust play a more crucial role along the arcs. In sites dominated by dust, eolian dust input appears to be characterized by a nearly uniform grain size mode at $\sim 4 \mu \mathrm{m}$.

Applying the ${ }^{230} \mathrm{Th}$-normalization technique, our proxies yield a consistent pattern of uniform dust fluxes of $1-2 \mathrm{~g} / \mathrm{m}^{2} / \mathrm{yr}$ across the Subarctic North Pacific. Elevated eolian dust fluxes of $2-4 \mathrm{~g} / \mathrm{m}^{2} / \mathrm{yr}$ characterize the westernmost region off Japan and the southern Kurile Islands south of $45^{\circ} \mathrm{N}$ and west of $165^{\circ} \mathrm{E}$ along the main pathway of the westerly winds. The core-top based dust flux reconstruction is consistent with recent estimates based on dissolved thorium isotope concentrations in seawater from the Subarctic North Pacific. The dust flux pattern compares well with state-of-the-art dust model predictions in the western and central Subarctic North Pacific, but we find that dust fluxes are higher than modeled fluxes by $0.5-1 \mathrm{~g} / \mathrm{m}^{2} / \mathrm{yr}$ in the northwest, northeast and eastern Subarctic North Pacific. Our results provide an important benchmark for biogeochemical models and a robust approach for downcore studies testing dust-induced iron fertilization of past changes in biological productivity in the Subarctic North Pacific.
\end{abstract}

(C) 2013 Elsevier B.V. All rights reserved.

\section{Introduction}

Eolian dust is a major driver in the global climate system through its influence on light scattering and absorption (Harrison et al., 2001; Tegen and Fung, 1994), cloud and precipitation properties (Kaufman et al., 2002; Levin et al., 1996), and the oceanic biogeochemical cycles of carbon and nutrients as a result of deliv-

\footnotetext{
* Corresponding author at: Lamont-Doherty Earth Observatory of Columbia University, 61 Route 9W, Palisades, NY 10964, USA. Tel.: +1 845365 8661; fax: +1 845 3658150.

E-mail address: sserno@ldeo.columbia.edu (S. Serno).
}

ering micronutrients like iron (Duce and Tindale, 1991; Jickells et al., 2005; Martin, 1990).

The Subarctic North Pacific (SNP) is one of the three principal High Nutrient-Low Chlorophyll (HNLC) regions of the world ocean, together with the equatorial Pacific and Southern Ocean. These regions are characterized by an excess pool of macronutrients delivered to the euphotic zone by mixing that is incompletely consumed during the annual biogeochemical cycle (Falkowski et al., 1998). The incomplete consumption has been explained by a lack of dissolved iron for which eolian dust is suggested to be the primary source in the SNP (e.g., Bishop et al., 2002; Duce and Tindale, 1991; Martin and Fitzwater, 1988; Martin et al., 1989; 


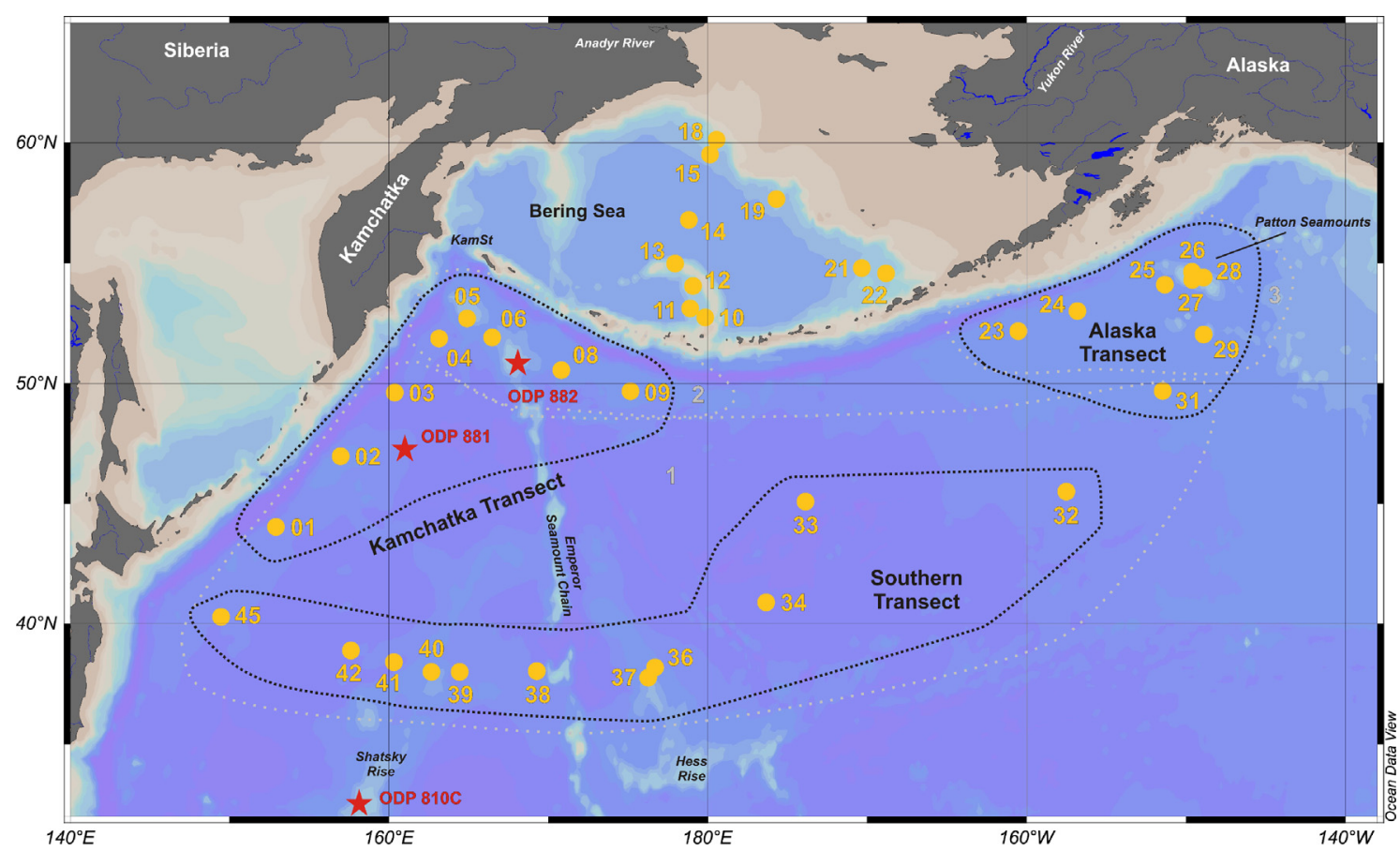

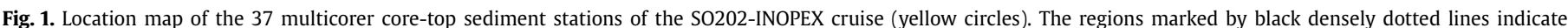

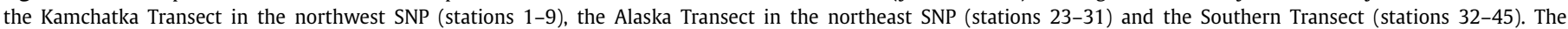

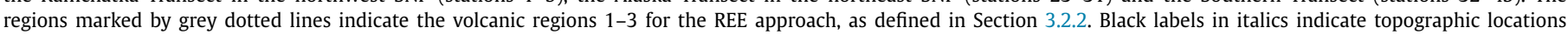

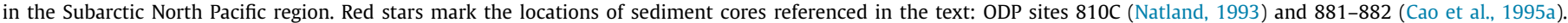

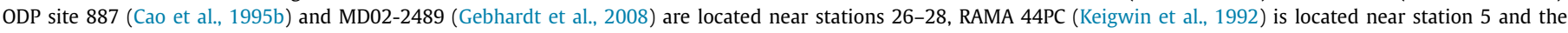

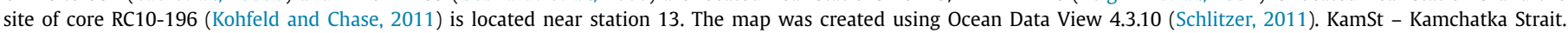
(For interpretation of the references to color in this figure legend, the reader is referred to the web version of this article.)

Rea, 1994). To test this hypothesis under modern conditions and in the past, we need reliable high-resolution dust records that are presently not available. The recent DIRTMAP3 compilation (Maher and Kohfeld, 2009, and references therein) with the addition of data based on surface water concentrations of dissolved aluminum (Measures et al., 2005) and ${ }^{230}$ Th-normalized ${ }^{232}$ Th fluxes (Kohfeld and Chase, 2011) show considerable variability in the Holocene spatial pattern of dust input to the SNP, varying between 0.1 and $21.4 \mathrm{~g} / \mathrm{m}^{2} / \mathrm{yr}$ without a clear geographical pattern. Therefore, most studies rely on dust model predictions. Model reconstructions are challenged by the complexity of the topography and local climatic settings of the East Asian dust source regions which can result in over- or under-representations of important sources like the Taklimakan desert (Luo et al., 2003; Tanaka and Chiba, 2006; Yumimoto et al., 2009). Since arid regions in East Asia are proposed to be the dominant dust sources to the SNP (e.g., Duce et al., 1980; Husar et al., 2001; Sun et al., 2001; Tanaka and Chiba, 2006; Uno et al., 2011), with potential minor contributions from North Africa, Middle East and Central Asia (Creamean et al., 2013; Hsu et al., 2012; Tanaka and Chiba, 2006), their complexity can result in uncertainties of model predictions for the SNP.

In this study, we present results from an extensive set of multicorer core-top sediments covering the SNP. In combination with biogenic component and grain size distribution data as well as ${ }^{230}$ Th-normalized mass accumulation rates (MARs), we reconstruct spatial dust flux patterns from three unique and independent geochemical tracers of dust: ${ }^{4} \mathrm{He},{ }^{232} \mathrm{Th}$ and rare earth elements (REEs). We use geochemical data from dominant East Asian dust sources for long-range atmospheric transport (Ferrat et al., 2011; McGee, 2009) and from volcanic ash layers from ODP sites in the SNP (Cao et al., 1995a, 1995b) as lithogenic endmembers to determine the sedimentary dust component. We compare the proxy results with each other to verify their potential as dust flux proxies and compare our results to model estimates and published observational data.

\section{Study area, material and methods}

\subsection{Study area and material}

Samples from the top one $\mathrm{cm}$ were used from 37 multicorer sediment cores recovered during the SO202-INOPEX cruise in 2009 (Fig. 1; Table 1; Gersonde, 2012). The Kamchatka Transect in the northwest SNP consists of stations 1-9, the Alaska Transect in the northeast SNP of stations 23-31 and the Southern Transect of stations 32-45 (Fig. 1). Sediment lithology varies over the cruise track from clay-bearing diatomaceous muds at stations $10-12$ in the southern Bering Sea to foraminiferal sands at shallower stations like station 26 on the Patton Seamounts in the northeast SNP. We have not determined dust fractions and fluxes from Bering Sea stations 10-22 because it is not possible to quantitatively deconvolve riverine input in the Bering Sea from East Asian dust, as described in the Supplementary Information, Section 1.

Linear sedimentation rates (LSRs) along the cruise track are highly variable (Table 1 ). They can be as low as $0.5 \mathrm{~cm} / \mathrm{kyr}$ or lower for the deeper stations along the Southern Transect (stations $32,33,34,36,38,39,41,42,45$ ), based on paleomagnetic observations (Opdyke and Foster, 1970; Lucia Korff, University of Bremen, personal communication). Along the Kamchatka and Alaska Transects, LSRs are found to be $>4 \mathrm{~cm} / \mathrm{kyr}$ based on paleomagnetic data (Opdyke and Foster, 1970). This is supported by results from sediment core RAMA 44PC, located on the Meiji Seamount in the northwest SNP nearby station 5 (Fig. 1), indicating LSRs between 7 and $29 \mathrm{~cm} / \mathrm{kyr}$ (Keigwin et al., 1992). Gebhardt et al. 
Table 1

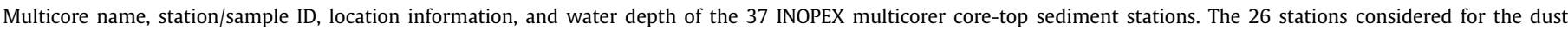

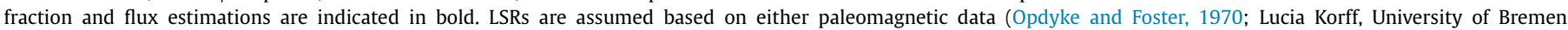

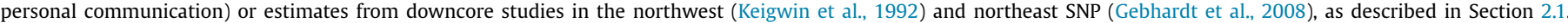
No LSR information is available for stations 37 and 40.

\begin{tabular}{|c|c|c|c|c|c|c|}
\hline Multicore name & $\begin{array}{l}\text { Station/sample } \\
\text { ID }\end{array}$ & $\begin{array}{l}\text { Latitude } \\
\left({ }^{\circ} \mathrm{N}\right)\end{array}$ & $\begin{array}{l}\text { Longitude } \\
\left({ }^{\circ} \mathrm{E}\right)\end{array}$ & Location & $\begin{array}{l}\text { Water depth } \\
(\mathrm{m})\end{array}$ & $\begin{array}{l}\text { LSR } \\
(\mathrm{cm} / \mathrm{kyr})\end{array}$ \\
\hline SO202-1-3 & 1 & 44.0259 & 152.9199 & Off Kurile Islands & 5282 & 6 \\
\hline SO202-2-4 & 2 & 46.9689 & 156.9821 & Off Kurile Islands & 4822 & 6 \\
\hline SO202-3-4 & 3 & 49.6141 & 160.3790 & Off Kurile Islands & 5429 & 6 \\
\hline SO202-4-3 & 4 & 51.8633 & 163.1604 & Off Kamchatka & 5273 & 6 \\
\hline SO202-5-3 & 5 & 52.6961 & 164.9193 & Northwestern Meiji Drift & 3362 & 6 \\
\hline SO202-6-2 & 6 & 51.9020 & 166.4902 & Northwestern Meiji Drift & 3422 & 5 \\
\hline SO202-8-1 & 8 & 50.5422 & 170.8213 & Detroit Seamount & 3630 & 5 \\
\hline S0202-9-2 & 9 & 49.6635 & 175.1615 & Northeastern Meiji Drift & 5028 & 4 \\
\hline SO202-10-2 & 10 & 52.7427 & 179.8478 & South of central Aleutian Trench & 1488 & \\
\hline SO202-11-1 & 11 & 53.1113 & 178.8999 & Southern Bowers Ridge & 2704 & \\
\hline SO202-12-2 & 12 & 54.0507 & 179.0877 & Southern Bowers Ridge & 2108 & \\
\hline SO202-13-4 & 13 & 54.9788 & 177.9572 & Central Bowers Ridge & 1383 & \\
\hline SO202-14-5 & 14 & 56.7863 & 178.8238 & Central Aleutian Basin & 3822 & \\
\hline SO202-15-4 & 15 & 59.5124 & 180.1508 & Northern Bering Slope & 3137 & \\
\hline SO202-18-1 & 18 & 60.1263 & 180.5567 & Northern Bering Slope & 1108 & \\
\hline SO202-19-5 & 19 & 57.6512 & 184.3217 & Bering Slope & 1751 & \\
\hline SO202-21-2 & 21 & 54.7888 & 189.6722 & Unimak Plateau & 1911 & \\
\hline SO202-22-1 & 22 & 54.5737 & 191.1877 & Unimak Plateau & 1478 & \\
\hline S0202-23-4 & 23 & 52.1727 & 199.4957 & South of eastern Aleutian Trench & 4613 & 4 \\
\hline S0202-24-2 & 24 & 53.0025 & 203.1930 & South of eastern Aleutian Trench & 4565 & 4 \\
\hline S0202-25-1 & 25 & 54.0985 & 208.6857 & South of eastern Aleutian Trench & 4588 & 6 \\
\hline SO202-26-1 & 26 & 54.6378 & 210.3835 & Patton Seamounts & 742 & 10 \\
\hline S0202-27-1 & 27 & 54.2962 & 210.4028 & Patton Seamounts & 2916 & 10 \\
\hline S0202-28-1 & 28 & 54.4018 & 211.1157 & Patton Seamounts & 3710 & 10 \\
\hline S0202-29-5 & 29 & 52.0280 & 211.1053 & Gibson Seamount & 3984 & 4 \\
\hline S0202-31-5 & 31 & 49.6775 & 208.5475 & Seamount in eastern SNP & 3744 & 4 \\
\hline SO202-32-5 & 32 & 45.5003 & 202.4998 & Abyssal Plain in eastern SNP & 5302 & 1 \\
\hline S0202-33-5 & 33 & 45.0838 & 186.1407 & North of Chinook Trough & 6159 & 1 \\
\hline S0202-34-4 & 34 & 40.8875 & 183.6760 & East of south Emperor Trough & 5713 & 0.5 \\
\hline SO202-36-6 & 36 & 38.1898 & 176.6966 & Northeastern Hess Rise & 4522 & 0.5 \\
\hline S0202-37-1 & 37 & 37.7675 & 176.2683 & Northern Hess Rise & 3573 & N/A \\
\hline S0202-38-1 & 38 & 38.0435 & 169.2812 & West of Ojin Seamount & 5503 & 1 \\
\hline S0202-39-2 & 39 & 38.0115 & 164.4467 & East of northern Shatsky Rise & 5096 & 1.66 \\
\hline SO202-40-2 & 40 & 38.0013 & 162.6848 & Northern Shatsky Rise & 3462 & N/A \\
\hline S0202-41-3 & 41 & 38.4132 & 160.3342 & West of northern Shatsky Rise & 5408 & 2 \\
\hline SO202-42-3 & 42 & 38.8917 & 157.6282 & Abyssal Plain in western SNP & 5535 & 1.74 \\
\hline SO202-45-2 & 45 & 40.2917 & 149.4850 & Abyssal Plain in western SNP & 5476 & 5 \\
\hline
\end{tabular}

(2008) find Holocene LSRs of $\sim 10 \mathrm{~cm} / \mathrm{kyr}$ nearby stations $26-28$ in core MD02-2489 from the Patton Seamounts. Because of these relatively high LSRs and since the sediment-water interface was successfully collected in the multicorer tubes during the INOPEX cruise (Gersonde, 2012), we assume modern age for the core-top sediment samples at all but the deep Southern Transect stations. Independent age constraints for the surface samples are not available.

\subsection{Methods}

For all INOPEX core-top samples, we analyzed helium isotopes, $\mathrm{U} / \mathrm{Th}$ isotopes, REE, calcium carbonate and biogenic opal concentrations at Lamont-Doherty Earth Observatory (LDEO) following published procedures. All concentration data were corrected for the contribution of salt to the dry sample weight. For 23 of the 37 samples, grain size analyses were performed at the Bentley University Particle Size Laboratory following the method described in Machalett et al. (2008). We further determined three endmember Weibull functions (EM1-EM3) that best described the observed size distributions and estimated the relative abundance of each endmember in each sample using the iterative least-square method described in McGee et al. (2013). For five East Asian dust source samples, we analyzed REE concentrations in the bulk, 0-4 and 4-8 $\mu \mathrm{m}$ size fractions. Detailed information about the analytical methods as well as uncertainties of the analyses are provided in the Supplementary Information, Section 2.

\section{Results}

All INOPEX core-top data and dust source data are available in Supplementary Datasets 1 and 2 and through PANGAEA (doi.pangaea.de/10.1594/PANGAEA.823124).

\subsection{Grain size distribution}

For the 23 analyzed samples, we can observe three dominant lithogenic endmembers (Fig. 2). The fine endmember with a mode at $\sim 4 \mu \mathrm{m}$ is the dominant endmember for all stations of the Southern Transect, and is also present along the other transects. Some samples of the Kamchatka and Alaska Transects show a slightly coarser mode for this endmember at $\sim 4.5-5 \mu \mathrm{m}$. The other two endmembers with coarser modes at $\sim 20$ and $45 \mu \mathrm{m}$, respectively, are observed in the size distributions of all samples, but only become significant for the stations of the Kamchatka and Alaska Transects along the volcanic arcs (Fig. 2).

Using the method of McGee et al. (2013), we determined three endmember Weibull functions EM1-EM3 with mode values of 4, 25, and $44 \mu \mathrm{m}$, respectively (Supplementary Fig. S1), that best described the observed size distributions, and estimated the relative abundance of each endmember in each sample. 

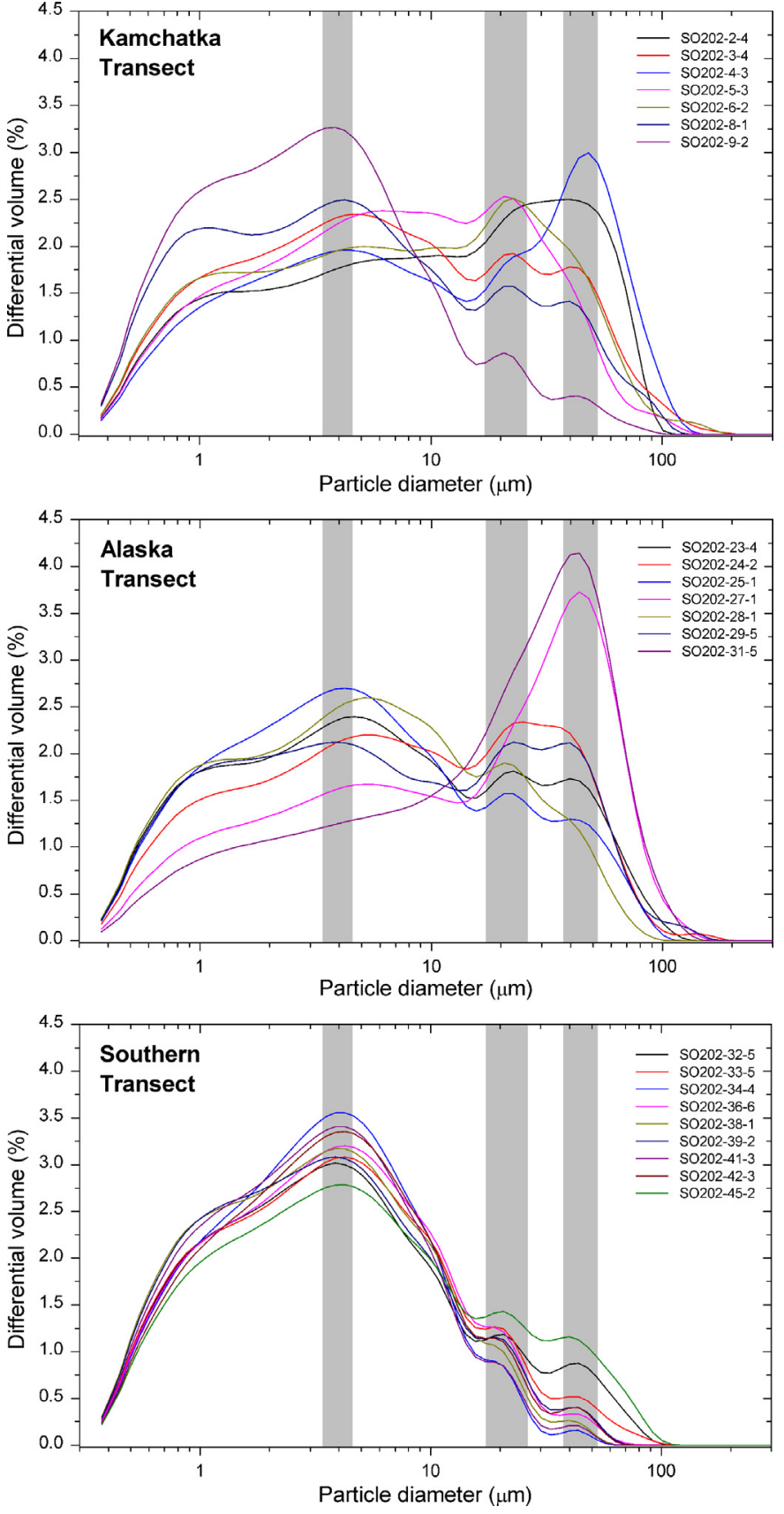

Fig. 2. Grain size distribution data for 23 INOPEX multicorer core-top sediment samples. Station samples 2-9 from the Kamchatka Transect (top), samples 23-25 and 27-31 from the Alaska Transect (middle) and samples 32-36, 38, 39 and 41-45 from the Southern Transect (bottom) are presented. From the 92 reported bins, only the differential volume data from the bins ranging from 0.38 to $300 \mu \mathrm{m}$ are shown since contributions from particle size classes $>300 \mu \mathrm{m}$ are negligible. The grey bars indicate the three grain size endmembers at $\sim 4,20$ and $45 \mu \mathrm{m}$.

\subsection{Dust fractions}

We used different geochemical proxies, ${ }^{4} \mathrm{He},{ }^{232} \mathrm{Th}$ and REE, measured in the INOPEX core-top samples, in combination with information about dust and volcanic endmembers, to determine the dust fraction of each sample, defined as the dust contribution to the lithogenic (or non-biogenic) fraction of the marine sediments.

For quantitative comparisons of the marine sediment results with source area data, we normalize the proxy concentration measured in the bulk sediment, $[\mathrm{X}]_{\text {bulk }}$, to the lithogenic fraction:

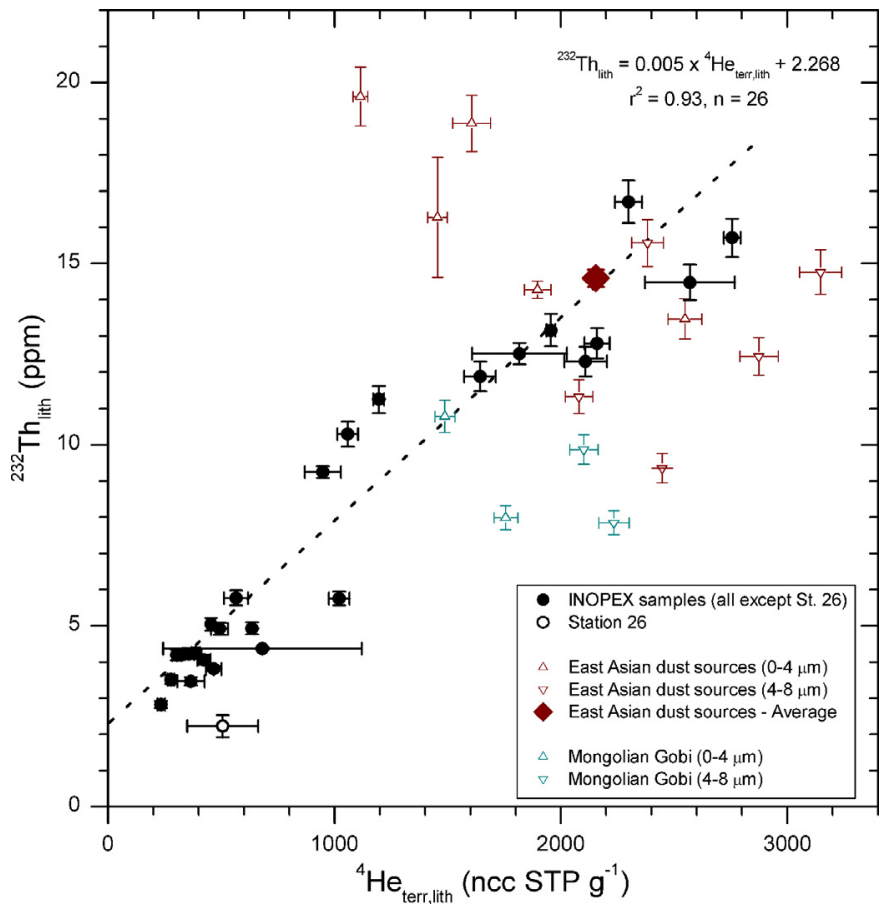

Fig. 3. Cross plot of salt-corrected ${ }^{232} \mathrm{Th}_{\text {lith }}$ and ${ }^{4} \mathrm{He}_{\text {terr,lith }}$ concentrations in the selected INOPEX core-top sediment samples. The INOPEX samples from the Kamchatka, Alaska and Southern Transects are shown as black circles (station sample 26 shown as an open circle). The regression line of the 26 selected samples is shown as a dashed line with the linear regression and coefficient of determination. Data from the $0-4$ and 4-8 $\mu \mathrm{m}$ size fractions of Taklimakan desert samples TK-074, TK-083 and TK-103, Badain Jaran desert sample BJ-024 and Tengger desert sample TG-018 are shown as open ruby colored triangles (McGee, 2009). The mean of all these size fraction samples is shown as a ruby colored quad. Data from the 0-4 and 4-8 $\mu \mathrm{m}$ size fractions from Mongolian Gobi desert samples MG-17 and MG-23 are presented with open turquois triangles (McGee, 2009).

$[\mathrm{X}]_{\text {lith }}=\frac{[\mathrm{X}]_{\text {bulk }}}{\left(100-\% \mathrm{CaCO}_{3}-\% \text { opal }\right) / 100}$

where $[\mathrm{X}]_{\text {lith }}$ is the proxy concentration in the lithogenic fraction.

Total organic carbon in the INOPEX sediments is typically $<1 \%$ (Méheust et al., 2013) and therefore negligible for calculating the lithogenic fraction.

\subsection{1. ${ }^{4} \mathrm{He}$ terr and ${ }^{232}$ Th approaches}

Concentrations of ${ }^{232} \mathrm{Th}_{\text {lith }}$ and ${ }^{4} \mathrm{He}_{\text {terr,lith}}$, the terrigenous ${ }^{4} \mathrm{He}$ concentration (Supplementary Information, Section 2.3) in the lithogenic fraction, in our core-top samples are compared to dust source area samples (McGee, 2009; sample locations in Supplementary Fig. S2).

Concentrations of ${ }^{4} \mathrm{He}_{\text {terr,lith }}$ and ${ }^{232} \mathrm{Th}_{\text {lith }}$ show a wide range, with ${ }^{4} \mathrm{He}_{\text {terr,lith }}$ varying between $235-2757$ ncc STP $\mathrm{g}^{-1}$ (ncc STP $\mathrm{g}^{-1}=$ nano cubic centimeter per gram at standard temperature and pressure) and ${ }^{232} \mathrm{Th}_{\text {lith }}$ between $\sim 2-17 \mathrm{ppm}$. All samples (except station 26 from the Alaska Transect) plot along a well-defined regression line $\left(r^{2}=0.93, n=26\right.$; Fig. 3$)$, indicating that the lithogenic fraction of these 26 selected INOPEX samples can be explained by binary mixing.

Source samples from the Taklimakan, Badain Jaran and Tengger deserts, representing the dominant East Asian dust sources for long-range transport (Supplementary Information, Section 3), scatter perpendicular to the regression line at the high ${ }^{4} \mathrm{He}_{\mathrm{terr}} /{ }^{232} \mathrm{Th}$ end of the INOPEX samples. Though studies of East Asian dust in Japan Sea sediments have attempted to distinguish between Taklimakan and Inner Mongolian dust sources (e.g., Nagashima et al., 2007, 2011), we are unable to determine the relative importance of these sources in the SNP sediments included in this study. We 
therefore determined the weighted mean eolian dust endmember concentrations from the $0-4$ and $4-8 \mu \mathrm{m}$ size fractions of samples from these sources, with all size fractions equally contributing to the mean value $\left({ }^{4} \mathrm{He}_{\text {dust EM }}\right.$ and ${ }^{232} \mathrm{Th}_{\text {dust EM}}$, respectively; Supplementary Information, Section 4.1). This weighted mean falls nearly on the mixing line defined by the selected INOPEX samples (Fig. 3). The good match between the mean of the source and the surface sediment samples enables us to use the dust source mean as the lithogenic endmember on the higher end of the regression line, with ${ }^{4} \mathrm{He}_{\text {dust EM }}$ and ${ }^{232} \mathrm{Th}_{\text {dust EM }}$ concentrations of $2155 \pm 21 \mathrm{ncc}$ STP $\mathrm{g}^{-1}$ and $14.6 \pm 0.2 \mathrm{ppm}$, respectively.

The other dominant lithogenic component in this region is interpreted to represent volcanic input (e.g., Bailey, 1993; Maeda et al., 2007; Nakai et al., 1993; Olivarez et al., 1991; Otosaka et al., 2004; Shigemitsu et al., 2007; Weber et al., 1996). Volcanic ashes from subduction-related volcanic arcs are known to be effectively helium-free in comparison to continental dust (Patterson et al., 1999; Supplementary Information, Section 2.3). We therefore determined the ${ }^{232} \mathrm{Th}$ concentration in the volcanic endmember $\left({ }^{232} \mathrm{Th}_{\mathrm{volcanic}} \mathrm{EM}\right)$ to be $2.3 \mathrm{ppm}$ based on the $y$-intercept of the regression line of the INOPEX samples (Fig. 3 ).

Since East Asian dust is the only source of ${ }^{4} \mathrm{He}$ to the marine sediments (Patterson et al., 1999; Winckler et al., 2005, 2008), we calculated the dust fraction for each sample $i$ as:

Dust fraction $_{\mathrm{He}}(i)=\frac{{ }^{4} \mathrm{He}_{\mathrm{terr}, \text { lith }}(i)}{{ }^{4} \mathrm{He}_{\text {dust EM }}}$

We calculated ${ }^{232}$ Th-based dust fractions with a simple twoendmember mixing model for each sample $i$ as:

Dust fraction $_{\mathrm{Th}}(i)=\frac{\left({ }^{232} \mathrm{Th}_{\mathrm{lith}}(i)-{ }^{232} \mathrm{Th}_{\text {volcanic EM }}\right)}{\left({ }^{232} \mathrm{Th}_{\mathrm{dust} \mathrm{EM}}-{ }^{232} \mathrm{Th}_{\text {volcanic EM }}\right)}$

\subsubsection{REE approach}

For the REE approach, we used the ratios of the sum of the heavy REEs (HREE; Ho, Er, Tm, Yb, Lu) normalized by upper continental crust (UCC) values after Taylor and McLennan (1985) to the sum of all UCC-normalized REE values ( $\Sigma$ HREE/ $\Sigma$ REE) as well as the ratio of the sum of UCC-normalized light REEs (LREE; La, $\mathrm{Ce}, \mathrm{Pr}, \mathrm{Nd})$ to the sum of all UCC-normalized REEs ( $\Sigma$ LREE $/ \Sigma$ REE). The $\Sigma$ HREE/ $\Sigma$ REE and $\Sigma$ LREE/ $\Sigma$ REE ratios of the 26 selected INOPEX samples vary between $0.34-0.46$ and $0.14-0.31$, respectively (Fig. 4). The REE data present a similar picture to the ${ }^{4} \mathrm{He}_{\text {terr }}$ and ${ }^{232} \mathrm{Th}$ data, with the INOPEX samples falling on well-defined regression lines. Therefore, we can deconvolve the lithogenic components in the sediments using a binary mixing model with East Asian dust and volcanic endmembers (Fig. 4). The East Asian dust endmember is derived from the mean of the same source material and size fractions as used for the ${ }^{4} \mathrm{He}_{\text {terr }}$ and ${ }^{232} \mathrm{Th}$ approaches (Ferrat et al., 2011; this study), with $\Sigma$ HREE/ $\Sigma R^{2} E_{\text {dust }}$ EM and $\Sigma$ LREE $/ \Sigma$ REE $_{\text {dust EM }}$ ratios of $0.35 \pm 0.02(1 \sigma)$ and $0.26 \pm 0.01$ $(1 \sigma)$, respectively. The REE characteristics of the selected INOPEX samples in comparison with the possible volcanic input (Supplementary Fig. S3) indicate that there may be three different volcanic endmembers with slightly different REE signatures, due to disparate volcanic inputs along the cruise track. Therefore, the samples were divided into three groups, with volcanic region 1 made up of stations $1-3$ and 31-45, volcanic region 2 of stations 4-9, and region 3 of stations 23-25 and 27-29 (Fig. 1). Volcanic ash layers are the best representatives of the volcanic input to marine sediments presently available for the SNP because transport-related compositional changes can occur and change the geochemical signature between the source and deposition site. Therefore, the volcanic endmembers have been derived from volcanic ash layer compilations (Cao et al., 1995a, 1995b) from ODP

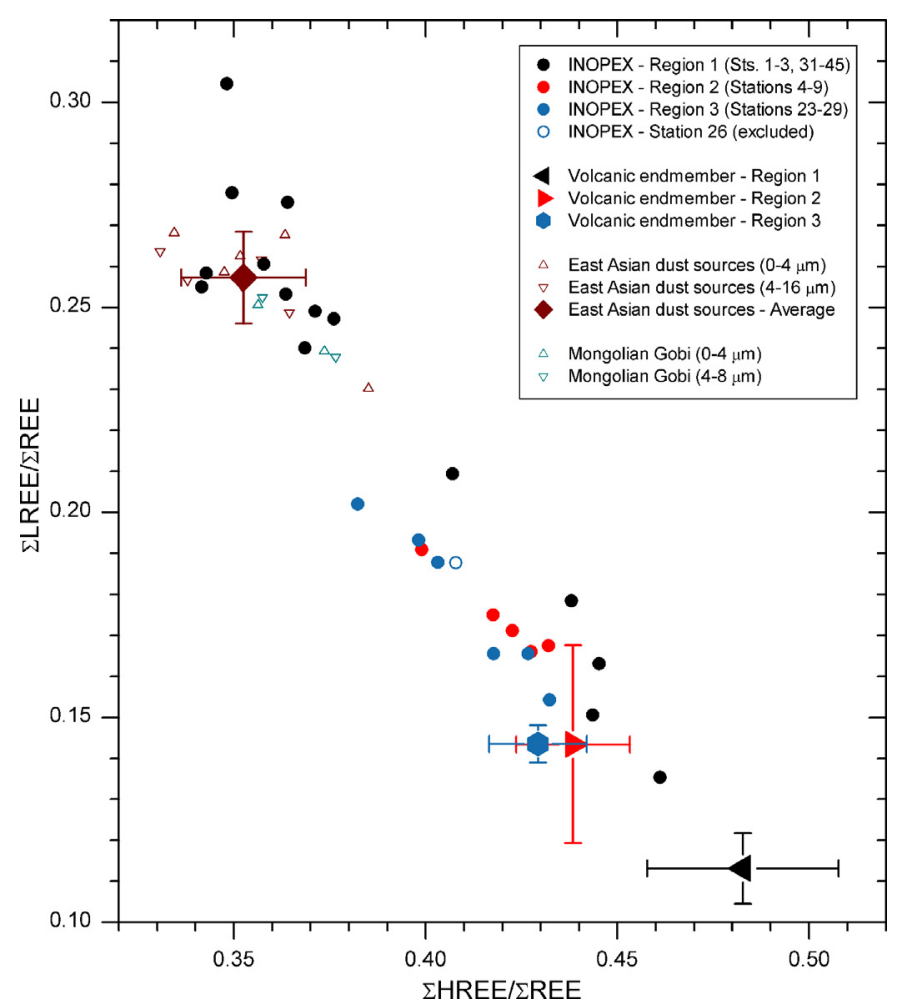

Fig. 4. $\Sigma$ HREE/ $\Sigma$ REE and $\Sigma$ LREE/ $\Sigma$ REE ratio data from the 27 INOPEX multicorer core-top sediment samples shown in Fig. 3. The samples from stations 1-3 and 31-45 (black circles) correspond to volcanic region 1 with the volcanic endmember shown as a black triangle. Samples from stations 4-9 (red circles) belong to volcanic region 2 characterized by the volcanic endmember presented with a red triangle. The station samples 23-25 and 27-29 (blue circles) from the northeast SNP or volcanic region 3 indicate volcanic contributions from the endmember shown as a blue hexagon. Station 26, excluded from the ${ }^{4} \mathrm{He}_{\text {terr }}$ and ${ }^{232} \mathrm{Th}$ approaches, is shown as an open blue circle. No dust fraction estimates have been derived from this station. Data from the $0-4 \mu \mathrm{m}$ and $4-16 \mu \mathrm{m}$ size fractions of East Asian dust source samples TK-074, TK-103, BJ-024, and TG-018 (Ferrat et al., 2011) and 0-4 and 4-8 $\mu \mathrm{m}$ size fractions of TK-083 (this study) are shown as open ruby colored triangles. The mean of all these size fraction samples is presented with a ruby colored quad. Grain size fraction data from $0-4$ and $4-8 \mu \mathrm{m}$ size fractions of samples MG-17 and MG-23 (this study) are indicated as open turquois triangles.

site 881 for volcanic region 1, ODP site 882 for volcanic region 2, and ODP site 887 for volcanic region 3 (Fig. 1; see Supplementary Information, Section 4.2, for more details). Resulting $\Sigma$ HREE $/ \Sigma$ REE $_{\text {volcanic EM }}$ and $\Sigma$ LREE/ $\Sigma$ REE $_{\text {volcanic EM ratios, with } 1 \sigma}$ uncertainties, are $0.48 \pm 0.03$ and $0.11 \pm 0.01$ for volcanic region 1 , $0.44 \pm 0.02$ and $0.14 \pm 0.02$ for region 2 , and $0.43 \pm 0.01$ and $0.14 \pm 0.01$ for region 3 .

REE-based dust fractions have been determined by assuming a linear two-endmember mixing model with orthogonal projections of the INOPEX sediments onto the mixing line between the mean East Asian dust and representative volcanic endmembers. The dust fraction from this projected point with $\Sigma \mathrm{HREE} / \Sigma \mathrm{REE}_{\text {proj }}$ and $\Sigma$ LREE $/ \Sigma$ REE $_{\text {proj }}$ for each sample $i$ is:

\section{Dust fraction $_{\text {REE }}(i)$}

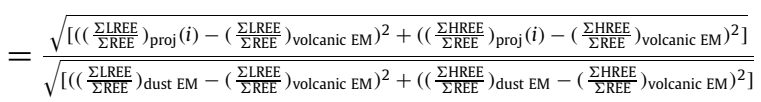

Uncertainties in the REE-based dust fractions were calculated using the maximum deviation of the dust fraction results from the mean endmembers of all point combinations from the error ellipsoids of the two endmembers.

For samples with calculated dust fractions $>100 \%$, we assumed that East Asian dust comprises $100 \%$ of the lithogenic input, with 

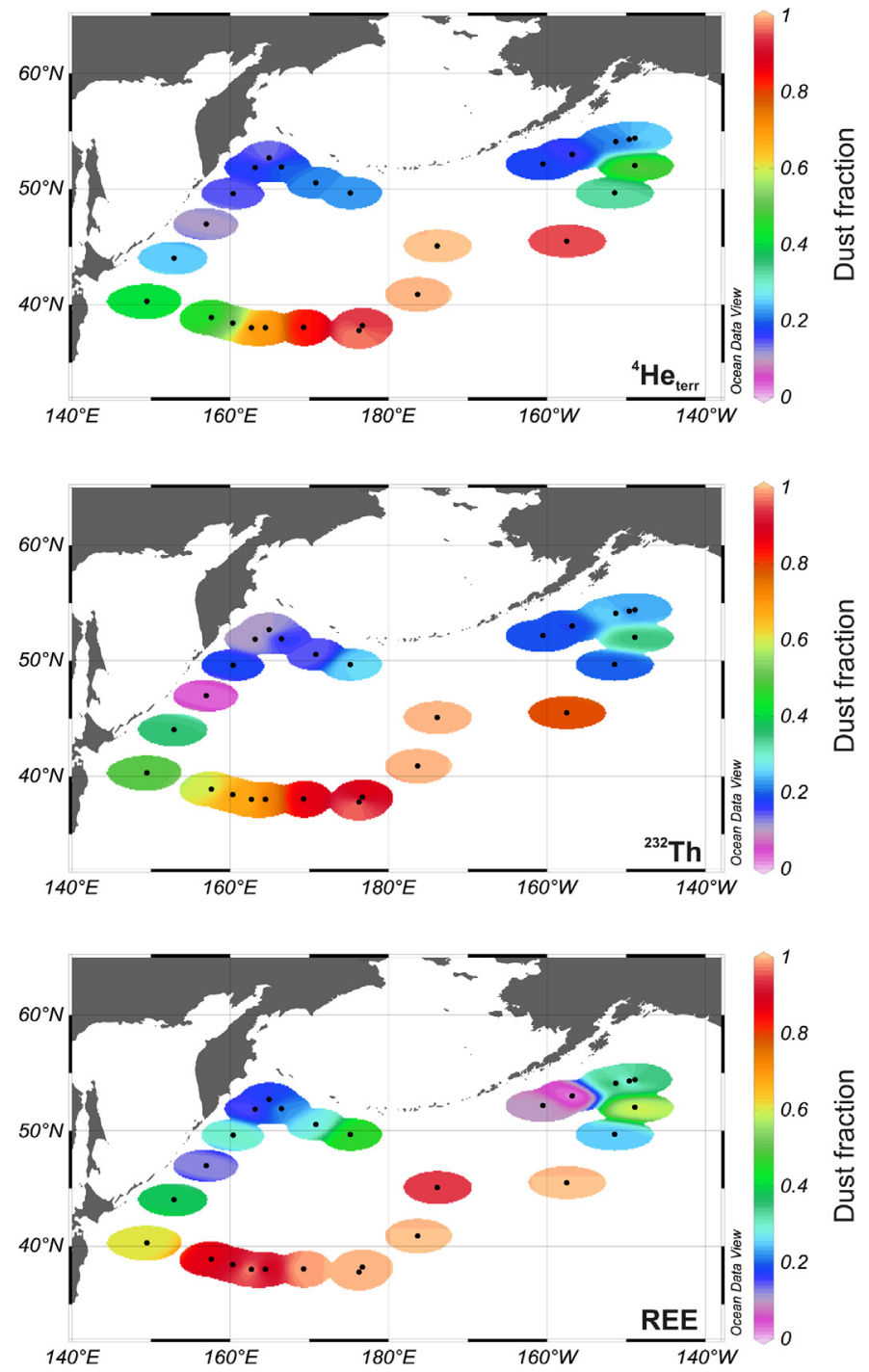

Fig. 5. Dust contributions to the lithogenic fraction for the 26 selected INOPEX multicorer core-top sediment samples shown in Figs. 3 and 4 from the three geochemical tracers ${ }^{4} \mathrm{He}_{\text {terr }}{ }^{232} \mathrm{Th}$, and REE. The black dots indicate the locations of the sediment samples. The maps were visualized with a rectangular grid (VG gridding method) with $X$ and $Y$ scale-lengths of 40 and 36\%, respectively, using Ocean Data View 4.3.10 (Schlitzer, 2011).

determined uncertainty, for all three geochemical approaches for the subsequent calculation of dust fluxes.

\subsubsection{Dust contributions to the lithogenic fraction}

All three geochemical proxies show consistent results for the dust fractions in the SNP (Fig. 5). Eolian dust comprises $80-100 \%$ of the lithogenic input to the open ocean stations 32-38 of the Southern Transect (Fig. 5). This is consistent with previous studies suggesting a dominance of East Asian dust input in this region (Jones et al., 1994, 2000; Nakai et al., 1993; Olivarez et al., 1991; Weber et al., 1996). The dust component in the lithogenic fraction is diluted by terrigenous input with volcanic signatures closer to the volcanic arcs; stations 39-45 show dust contributions of $\sim 40-80 \%$. Terrigenous input with volcanic signatures dominates the lithogenic fraction in the samples from the Kamchatka and Alaska Transects while the dust fraction is typically smaller than $50 \%$. The REE approach shows slightly higher dust fractions along the Kamchatka Transect and higher variability in the fraction estimates along the Alaska Transect, compared to the ${ }^{4} \mathrm{He}_{\text {terr }}$ and ${ }^{232}$ Th approaches (Fig. 5).
The estimated fractions of the fine grain size endmember (EM1; mode $\sim 4 \mu \mathrm{m}$ ) from the Weibull modeling show good correlations with the dust fractions estimated from the three geochemical tracers for the open ocean stations 32-39 from the Southern Transect and stations 29 and 31 from the Alaska Transect (Fig. 6). Stations from the Kamchatka and Alaska Transects along the volcanic arcs indicate fine endmember fractions higher than dust fractions by a factor of 2-6. The westernmost stations 41-45 from the Southern Transect show smaller differences (factor of $\leqslant 2$ ) between the grain size modeling and geochemical proxy approaches.

\subsection{Dust fluxes}

Dust fluxes are calculated by multiplying the dust fractions by the ${ }^{230}$ Th-normalized MAR (calculated using Eq. (S2) in the Supplementary Information, Section 2.4):

$$
\begin{aligned}
\text { Dust flux }= & {\left[\text { Dust fraction } \times\left(100-\% \mathrm{CaCO}_{3}-\% \text { opal }\right) / 100\right] } \\
& \times \text { MAR }
\end{aligned}
$$

As mentioned in Section 2.1, LSRs can be as low as $0.5 \mathrm{~cm} / \mathrm{kyr}$ or even lower for the stations along the Southern Transect deeper than $4500 \mathrm{~m}$ (stations 32, 33, 34, 36, 38, 39, 41, 42, 45; Opdyke and Foster, 1970; Lucia Korff, University of Bremen, personal communication). Bioturbation within the sediment column at these stations can result in mixing of glacial sediments into the surface sediments.

The INOPEX cruise track allows us to test for potential bioturbation effects by comparing nearby stations 36 and 37 on the northern Hess Rise and stations 39 and 40 on the northern Shatsky Rise, respectively. For both paired stations, the shallow stations (37 and 40) are characterized by much greater LSRs than the deeper ones due to greater $\mathrm{CaCO}_{3}$ preservation.

The stations deeper than $4500 \mathrm{~m}$ along the Southern Transect show similar dust fluxes for the three geochemical approaches, varying between $1.75-2.65 \mathrm{~g} / \mathrm{m}^{2} / \mathrm{yr}$ for ${ }^{4} \mathrm{He}_{\text {terr }}, 2.06-3.05 \mathrm{~g} / \mathrm{m}^{2} / \mathrm{yr}$ for ${ }^{232} \mathrm{Th}$, and $2.25-3.37 \mathrm{~g} / \mathrm{m}^{2} / \mathrm{yr}$ for REE. Grain size modelingderived dust flux estimates show a similar range for the stations 32-39 (Supplementary Table S1). The deeper stations show dust fluxes $\sim 100-130 \%$ and $\sim 17-25 \%$ higher than the fluxes from the neighboring shallower ones for the pairs of stations 36/37 and 39/40, respectively (Fig. 7; Supplementary Table S1). Because these stations are in close proximity (Fig. 1), they are expected to have similar dust fluxes, but differ probably due to admixture of highdust glacial sediments into the surface sediments at the deeper stations.

Therefore, we conducted a bioturbation correction for all stations located deeper than $4500 \mathrm{~m}$ along the Southern Transect using a simple model with the assumption of a well mixed layer of $5 \mathrm{~cm}$ (e.g., Ruddiman and Glover, 1972). The model was run over the time period from 20-0 kyr BP with a constant LSR and time steps of 20 years. A simple two-step function with fluxes of $1 \mathrm{~g} / \mathrm{m}^{2} / \mathrm{yr}$ for the time since $11.64 \mathrm{kyr} \mathrm{BP}$ and $4 \mathrm{~g} / \mathrm{m}^{2} / \mathrm{yr}$ before $11.64 \mathrm{kyr} B P$ was used as the input signal (see Supplementary Information, Section 5, for MATLAB code). This assumption is based on results from a sediment core in the Southern Bering Sea (RC10-196; Kohfeld and Chase, 2011; Fig. 1), showing elevated dust fluxes through the Last Glacial Maximum until the end of the Younger Dryas stadial at $11.64 \mathrm{kyr}$ BP and a sudden drop by about a factor of 4 to lower dust fluxes during the present Holocene interglacial. We used the deviation of the modeled from the measured sediment dust flux value to determine the bioturbation-corrected dust fluxes and assumed an uncertainty of $30 \%$ for the final dust flux results due to uncertainties in the choice of the model parameters. 

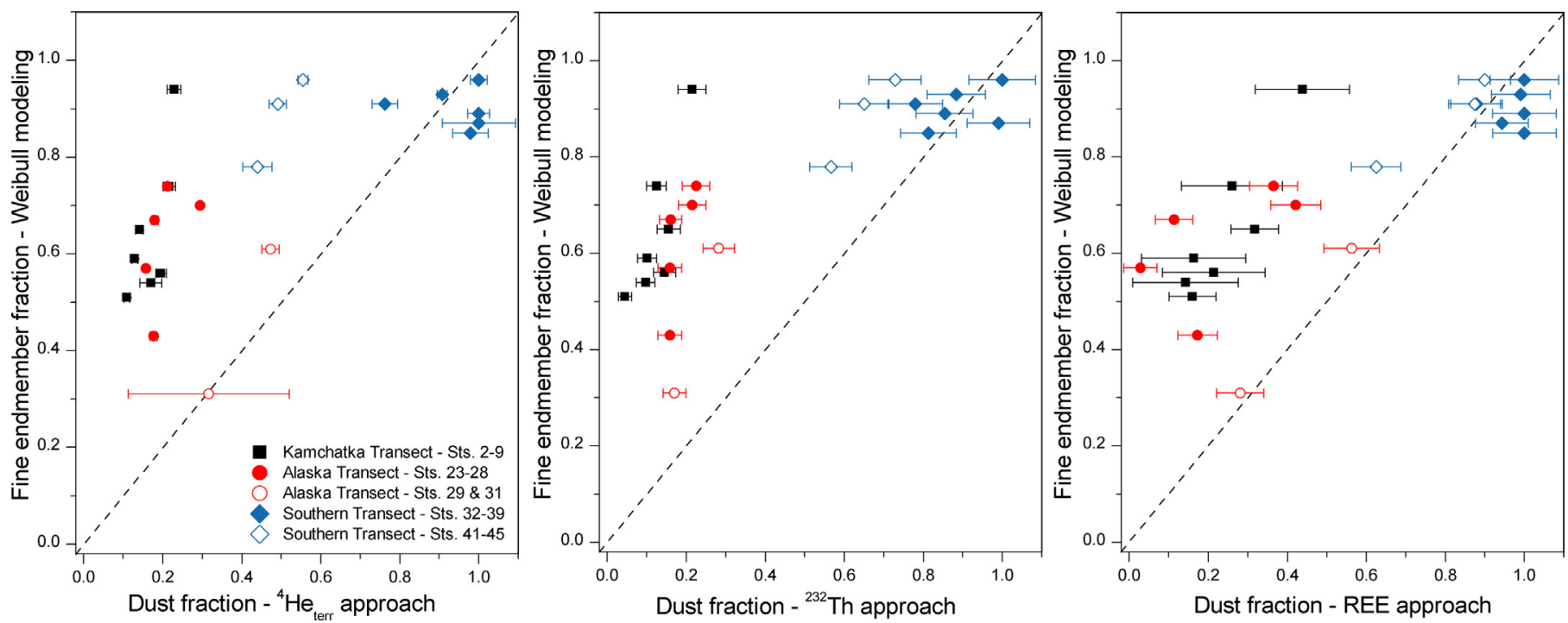

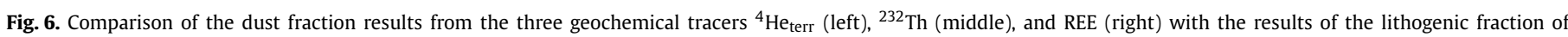

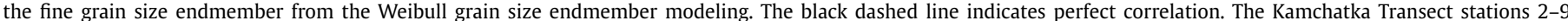

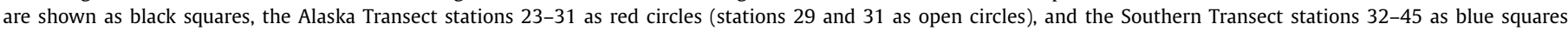

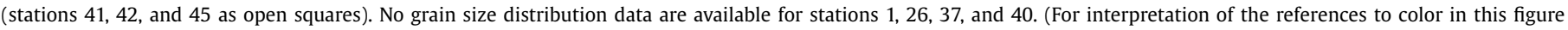
legend, the reader is referred to the web version of this article.)

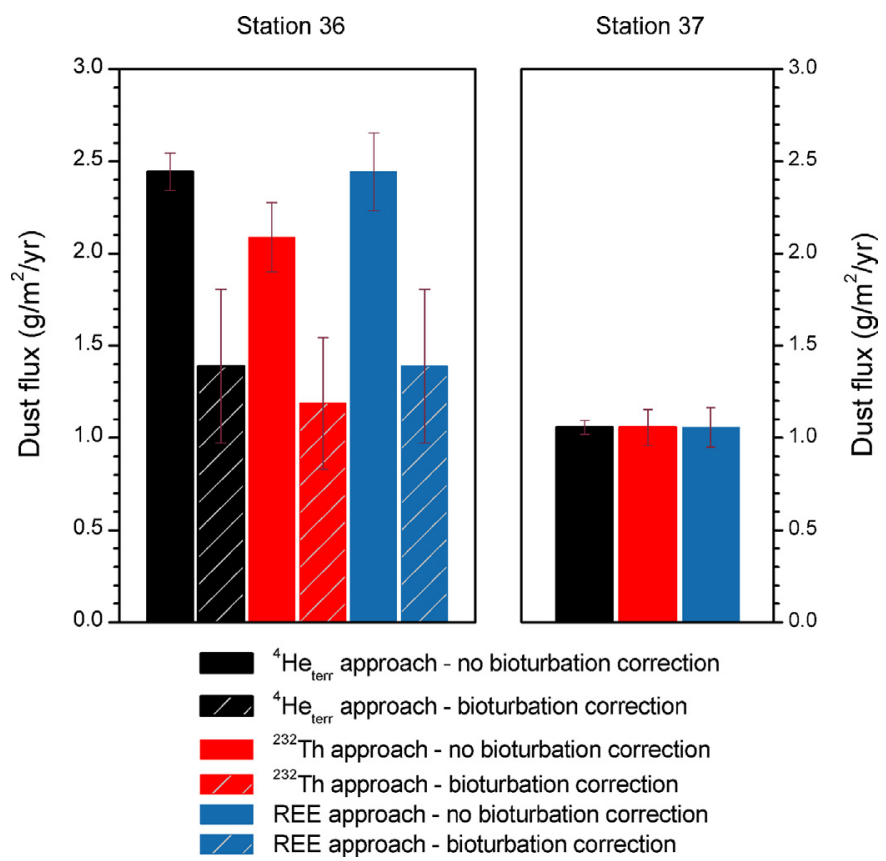

Fig. 7. Effect of bioturbation correction shown for station samples 36 and 37. Dust fluxes from station 36 have been corrected for bioturbation following the procedure described in the text. Fluxes from the neighboring station 37 from the northern Hess Rise have not been corrected because of high sedimentation rates. Dust fluxes based on ${ }^{4} \mathrm{He}_{\text {terr }}$ (black), ${ }^{232} \mathrm{Th}$ (red) and REE (blue) are shown; bioturbationcorrected dust fluxes are presented with striped columns.

Bioturbation-corrected dust fluxes from the deep stations vary between $1.22-2.37 \mathrm{~g} / \mathrm{m}^{2} / \mathrm{yr}$ for the ${ }^{4} \mathrm{He}_{\text {terr }}$ approach, $1.19-$ $3.05 \mathrm{~g} / \mathrm{m}^{2} / \mathrm{yr}$ using ${ }^{232} \mathrm{Th}$, and $1.28-3.36 \mathrm{~g} / \mathrm{m}^{2} / \mathrm{yr}$ using REEs (Supplementary Table S1). A valuable test for the validity of our bioturbation correction is the comparison of uncorrected and corrected dust fluxes from stations $36 / 37$ and 39/40. Corrected dust fluxes for the deeper station 36 correlate very well with the uncorrected fluxes from the shallower station 37 (Fig. 7), deviating by a maximum of $30 \%$ for the different approaches and therefore correlate well within their uncertainty. Similarly, the maximum deviation between the corrected fluxes from deep station 39 and uncorrected dust fluxes from the higher-LSR station 40 is $\sim 5 \%$ for the three geochemical approaches. Assuming that each of these pairs of stations should have similar dust fluxes due to their proximity to each other, these findings indicate that our bioturbation corrections are both valid and necessary.

At INOPEX stations with sedimentation rates $>4 \mathrm{~cm} / \mathrm{kyr}$, a bioturbation correction is not required. For example, the bioturbation correction at station 45 , with an approximate LSR of $5 \mathrm{~cm} / \mathrm{kyr}$, results in deviations of $<0.1 \%$ of the bioturbation-corrected dust fluxes from the input signal of $1 \mathrm{~g} / \mathrm{m}^{2} / \mathrm{yr}$ for the top one $\mathrm{cm}$ for all three geochemical tracers. Consequently, bioturbation-corrected dust fluxes deviate from the measured dust flux values by $<0.1 \%$ at this station (Supplementary Table S1).

The resulting maps of dust flux patterns across the Subarctic North Pacific are discussed in Section 4.3.

\section{Discussion}

Determining the eolian dust component in near-land regions of the SNP is a geochemical challenge because a significant fraction of the lithogenic input may originate from other sources. A major source is volcanic ash from the surrounding Kurile, Aleutian, Kamchatka, Alaska and Japan volcanic arcs (Bailey, 1993; Jones et al., 1994, 2000; Maeda et al., 2007; Nakai et al., 1993; Olivarez et al., 1991; Otosaka et al., 2004; Shigemitsu et al., 2007; Weber et al., 1996). Also contributing to the lithogenic fraction are hemipelagic material (Jones et al., 1994, 2000), ice-rafted debris (IRD; McKelvey et al., 1995; St. John and Krissek, 1999) and fine riverine material transported by ocean currents (van de Flierdt et al., 2003; VanLaningham et al., 2009). Turbidites are unlikely to influence the INOPEX stations since they are separated from the margins by deep trenches.

\subsection{Grain size distributions in Subarctic North Pacific sediments}

The grain size distribution data indicate that different components contribute to the sedimentary lithogenic fraction. Most of the samples show a clear and constant grain size mode at $\sim 4 \mu \mathrm{m}$. This component represents the dominant endmember along the Southern Transect (Fig. 2). Previous grain size studies 
from the North Pacific (Rea and Hovan, 1995; Rea and Leinen, 1988), western North America (Zdanowicz et al., 2006) and Greenland (Biscaye et al., 1997; Svensson et al., 2000) suggest a dominant East Asian dust grain size mode at $\sim 3-4 \mu \mathrm{m}$. The good correlation of the estimated fractions of the fine grain size endmember EM1 at $\sim 4 \mu \mathrm{m}$ from the Weibull endmember modeling and the dust fractions from the geochemical approaches along the Southern Transect (Fig. 6) suggests that the fine grain size endmember EM1 represents East Asian eolian dust. The remarkable uniformity of the dust mode over the entire SNP supports previous studies indicating little change in the eolian dust size distribution beyond 1000-2000 km from the source (Rea, 1994; Rea and Hovan, 1995).

Comparison of grain size and geochemical endmember abundances indicates that the abundance of the fine grain size endmember exceeds the geochemically-derived dust contribution by a factor of 2-6 along the volcanic arcs at stations 2-9 from the Kamchatka Transect and 23-28 from the Alaska Transect (Fig. 6). Some stations along the Kamchatka and Alaska Transects close to the volcanic arcs further show a slightly coarser mode for the fine grain size endmember at $\sim 4.5-5 \mu \mathrm{m}$ (Fig. 2). These findings indicate a pronounced contribution of lithogenic material other than dust to this endmember. Possible components are fine eolian volcanic input, fluvial input or fine-grained material from resuspended shelf sediments (Rea and Hovan, 1995). The two coarser endmembers with modes at $\sim 20$ and $45 \mu \mathrm{m}$, which dominate in most of the marginal stations (Fig. 2), cannot be explained by eolian input as these modes are too coarse to be explained by long-range atmospheric transport (Rea and Hovan, 1995; Tsoar and Pye, 1987). The grain size endmember with a mode at $\sim 45 \mu \mathrm{m}$ is likely to be IRD. The other endmember with a mode at $20 \mu \mathrm{m}$ could be hemipelagic or riverine material transported to marginal stations (Rea and Hovan, 1995); airborne input from proximal volcanic provinces could also contribute to this endmember.

\subsection{Contribution of eolian dust to the marine sediments}

\subsubsection{Deconvolution of lithogenic components}

Most of the pioneering dust studies of the last $\sim 30$ years from the North Pacific have been based on a chemical leaching procedure that extracts the non-authigenic, inorganic, crystalline component and weighs the residue (Rea and Janecek, 1981). This method has been questioned because it causes compositional changes in the finer size fraction (Weber et al., 1998), and because it cannot chemically separate eolian dust from other lithogenic components, especially volcanic ash, potentially biasing estimates in a complex region like the SNP.

The grain size distribution data show that different components contribute to the lithogenic fraction of the sediments. The geochemical tracers ${ }^{4} \mathrm{He}_{\text {terr }},{ }^{232} \mathrm{Th}$ and REE indicate that the eolian dust input can be geochemically deconvolved using a binary mixing model with a fine-grained East Asian dust endmember and variable volcanic endmembers along the arcs (Figs. 3, 4). As the surrounding land is of volcanic origin, the hemipelagic and riverine input as well as IRD have a geochemical signature similar to the fine-grained volcanic ash (Jones et al., 1994; McKelvey et al., 1995; Otosaka et al., 2004; Shigemitsu et al., 2007) and are therefore accounted for by the volcanic endmembers.

All three geochemical approaches indicate a dominance of eolian dust input in the open ocean far away from the arcs (Fig. 5). Along the Kamchatka and Alaska Transects, terrigenous input other than dust dominates. The dust fraction results along the Alaska Transect are consistent with the results along the Kamchatka and Southern Transects and do not require pronounced input of eolian dust, glacial outwash or riverine material from Alaska (Boyd et al., 1998; Crusius et al., 2011). Since we presently have no reliable in- formation about continental material compositions and grain size distributions from this region, a local eolian or riverine contribution to the Alaska Transect cannot be conclusively excluded.

\subsubsection{Local uncertainties in the lithogenic component deconvolution}

Despite the good consistency among the three geochemical tracers in the lithogenic component deconvolution, local uncertainties remain for single stations.

At stations 8 and 9 in the easternmost part of the Kamchatka Transect, the eolian dust contribution appears higher than in the more western stations 4-6 (Fig. 5). Stations 8 and 9 are located on the Meiji drift, a sediment tongue consisting of claysized fluvial-derived debris from the Bering Sea originating from continental material in Alaska and Siberia (Scholl et al., 1977; van de Flierdt et al., 2003; VanLaningham et al., 2009). This continental material probably has a similar geochemical signature to eolian dust and could therefore lead to the overestimation of the dust component. However, the fine-grained continental material transported by the East Kamchatka Current from the Bering Sea into the northwest SNP through the Kamchatka Strait (Fig. 1) does not appear to contribute to the lithogenic fraction at stations 4-6 just south of the strait as this would be indicated by higher-than-expected dust contributions compared to neighboring stations (Fig. 5).

The REE approach indicates more variable dust fraction results along the Alaska Transect and higher dust contributions for the Southern Transect stations 39-45 and the Kamchatka Transect stations compared to the other geochemical approaches (Fig. 5). For the westernmost part of the Southern Transect, contribution of volcanic ash from Japan having ${ }^{4} \mathrm{He}_{\text {terr }}$ and ${ }^{232} \mathrm{Th}$ signatures similar to, and a REE signature different from, the volcanic material from the Kurile and Kamchatka arcs could explain the difference. A study of volcanic ash layers from ODP site $810 \mathrm{C}$ on the Shatsky Rise just south of station 40 (Fig. 1) indicates contributions from the Kurile Islands, Kamchatka and Hokkaido (Natland, 1993). Volcanic material from Hokkaido probably does not contribute to ODP site 881 off the Kurile Islands (Fig. 1), which is the volcanic endmember used for the Southern Transect. The higher dust fractions along the western part of the Southern Transect could alternatively be the result of lower HREE concentrations in eolian dust at the deposition site compared to the source. Since important REE host minerals like zircon are relatively LREE depleted (Gromet et al., 1984; Moreno et al., 2006; Taylor and McLennan, 1985), this could argue for a compositional change during transport from the source to the depositional site. On the other hand, we would expect similar changes for ${ }^{4} \mathrm{He}$ and ${ }^{232} \mathrm{Th}$. The reason for the higher variability in the dust fraction results along the Alaska Transect is unknown, but could be the result of local volcanic provinces contributing to individual stations. The higher dust fraction estimates along the Kamchatka Transect from the REE approach could be the result of an uncertainty in the volcanic endmember selection. For most of the stations, the dust fraction estimates correlate with the results of the other two geochemical approaches within their uncertainties, but only because the REE-based dust fraction results have large errors as a result of highly variable $\Sigma$ LREE/ $\Sigma$ REE ratios of the volcanic ash layers comprising the endmember mean from volcanic region 2 (Cao et al., 1995a). Future research to better define the REE concentrations of the volcanic provinces surrounding the SNP and contributing to the marine sediments appears to be of high significance because the provinces apparently show more variable REE concentrations than ${ }^{4} \mathrm{He}_{\text {terr }}$ and ${ }^{232} \mathrm{Th}$ (Figs. 3, 4). 

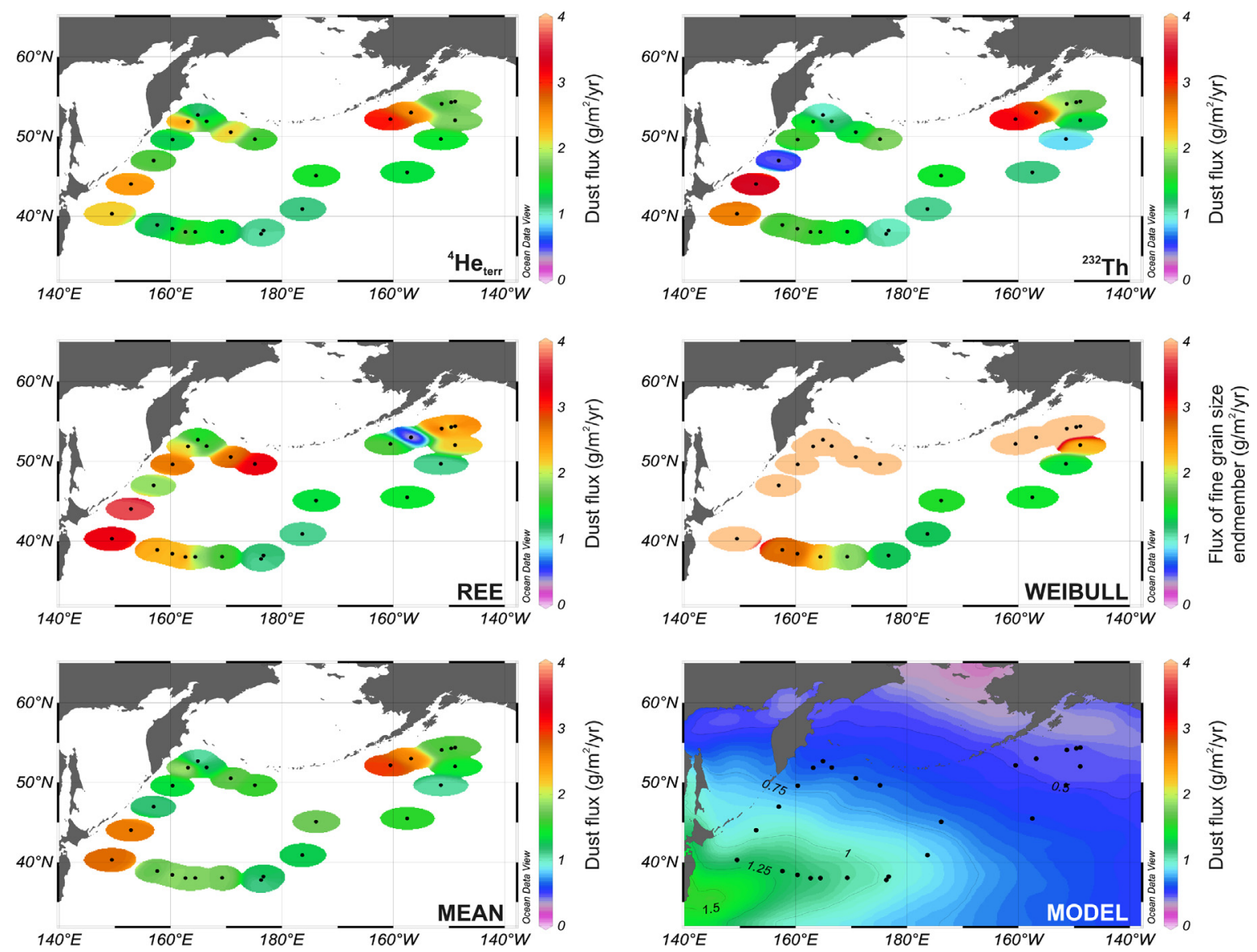

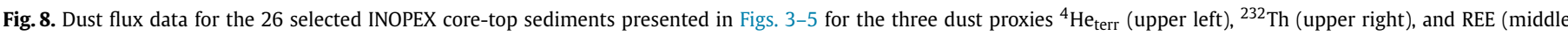

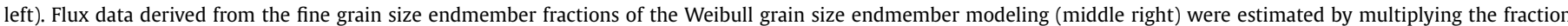

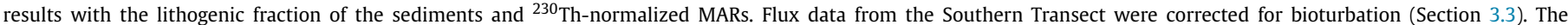

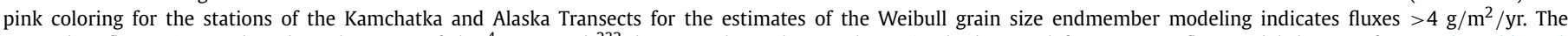

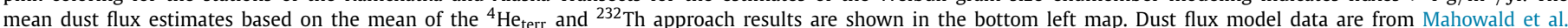

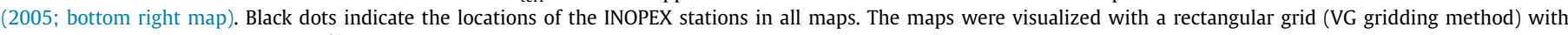
$X$ and $Y$ scale-lengths of 40 and 36\%, respectively, using Ocean Data View 4.3.10 (Schlitzer, 2011).

\subsection{Spatial dust flux pattern in the Subarctic North Pacific}

The three geochemical proxy approaches show good consistency in their dust flux results (Fig. 8). The highest dust fluxes of $\sim 2-4 \mathrm{~g} / \mathrm{m}^{2} / \mathrm{yr}$ are observed west of $\sim 165^{\circ} \mathrm{E}$ and south of $\sim 45^{\circ} \mathrm{N}$ in the southwestern part of the INOPEX cruise track, along the middle of the main pathway of the westerly jet transporting dust over the North Pacific (Husar et al., 2001; Uematsu et al., 2003; Weber et al., 1996; Yumimoto et al., 2009; Zhao et al., 2006). To the north and east of this region, dust fluxes gradually decrease to $\sim 1-2 \mathrm{~g} / \mathrm{m}^{2} / \mathrm{yr}$ over the remainder of the SNP. Fluxes derived from the fine grain size endmember fraction (see Sections 3.2.3 and 4.1; Fig. 6) show consistent results with the geochemically-derived dust fluxes for the Southern Transect, but overestimate the dust input along the arcs as a result of additional lithogenic contributions from fine eolian volcanic input and resuspended shelf sediments to this grain size mode (Fig. 8). Due to the overestimation of flux estimates derived from grain size endmember modeling and the discussed uncertainties for the REE approach at specific INOPEX stations (Section 4.2.2), our best estimate for dust fluxes in the SNP is derived from averaging the results from the ${ }^{4} \mathrm{He}_{\text {terr }}$ and ${ }^{232} \mathrm{Th}$ approaches, with an assigned uncertainty equal to the absolute deviation between the results of the two approaches from their mean for each sample (Figs. 8, 9).

At station 4 just south of the Kamchatka Strait and stations 23 and 24 of the Alaska Transect, the dust fluxes are a factor of 1.5-2 higher than at neighboring stations, suggesting an overestimation of the East Asian dust input (Fig. 8). The implied overestimation of the ${ }^{230}$ Th-normalized MARs at these stations could be the result of loss of the surface sediments due to erosion or slumping. This would lead to an exposure of old sediments resulting in an overestimation of the calculated ${ }^{230} \mathrm{Th}$-normalized MARs due to the failure to correct for radioactive decay of excess ${ }^{230} \mathrm{Th}$. Dust fluxes at stations 8 and 9 appear to be overestimated as a result of overestimated dust fractions (Section 4.2.2).

The sediment-based dust fluxes show uncertainties $\leqslant 30 \%$ for all except 6 stations (Fig. 9). Only samples from stations 4-6 show uncertainties $>50 \%$, and the uncertainties are this large only when using the REE approach. Uncertainties in the lithogenic endmembers contributing to the SNP dominate the overall uncertainty of the derived dust fluxes.

Results from state-of-the-art dust models, for example from a composite of three studies (Ginoux et al., 2001; Mahowald and Luo, 2003; Tegen et al., 2004) published in Mahowald et al. (2005), correlate well with the sedimentary dust fluxes in the western and central part of the Southern Transect (Figs. 8, 9). In the northwest, northeast and eastern SNP, our dust fluxes are higher than the model results by $\sim 0.5-1 \mathrm{~g} / \mathrm{m}^{2} / \mathrm{yr}$ or a factor of 20-80\% (Figs. 8, 9). A possible cause for this discrepancy could lie in difficulties faced by models in capturing the complex topography and fine-scale dust generation processes in East Asian 

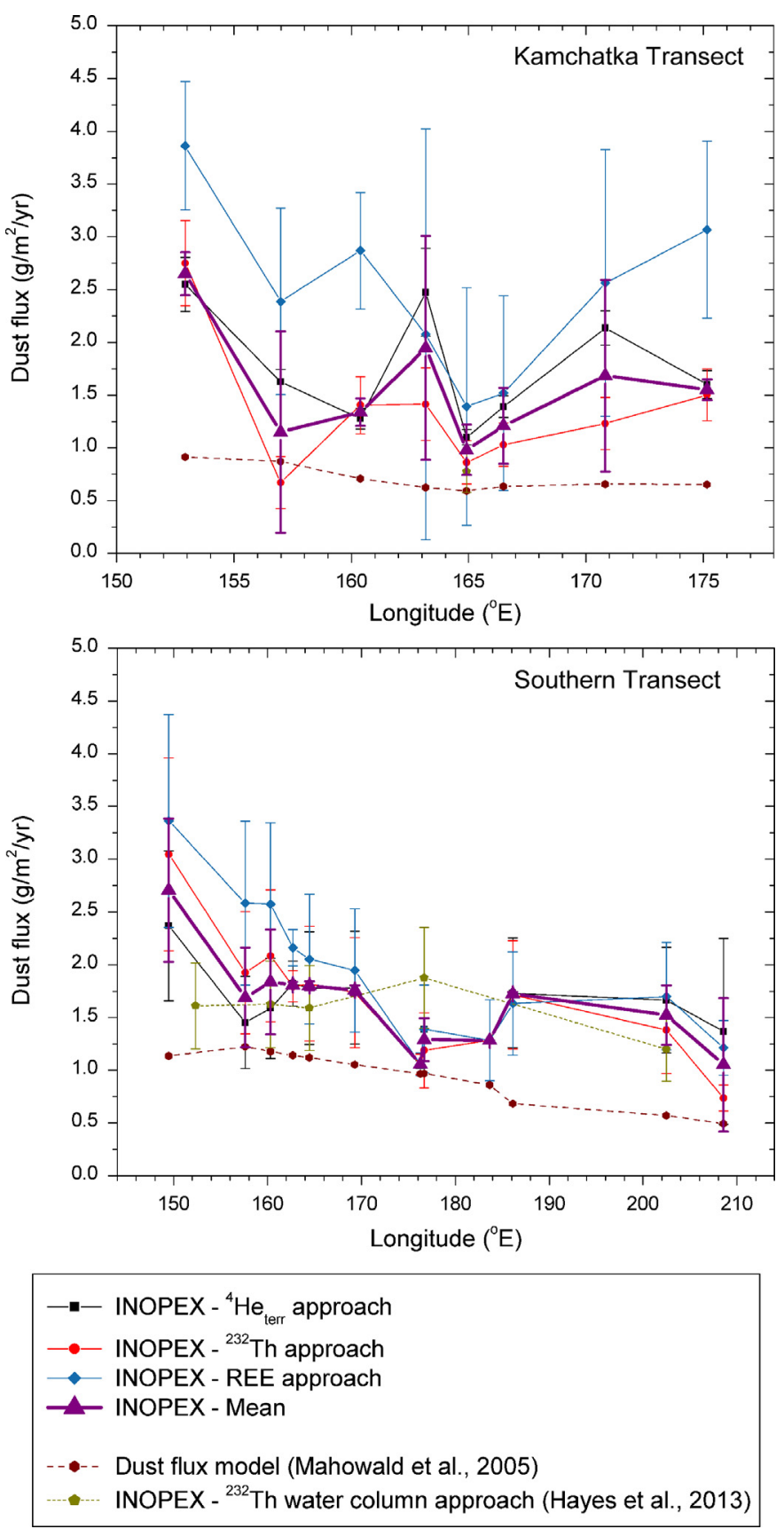

Fig. 9. Longitudinal transects of the sedimentary dust flux data from the ${ }^{4} \mathrm{He}_{\text {ter }}$ (black), ${ }^{232} \mathrm{Th}$ (red) and REE (blue) approaches for the Kamchatka Transect (top) and Southern Transect (bottom). For both transects, the mean dust flux estimates based on the mean of the ${ }^{4} \mathrm{He}_{\text {terr }}$ and ${ }^{232} \mathrm{Th}$ approach results with the absolute deviation between the proxy results from their mean as error are shown (purple). Dust flux results from the grid nearest to the corresponding INOPEX stations from the model dust deposition estimates (Mahowald et al., 2005) are presented with ruby colored symbols and dashed lines. Dust flux results based on dissolved thorium concentrations in seawater from a number of INOPEX stations are shown as moss green hexagons and dashed lines (Hayes et al., 2013). (For interpretation of the references to color in this figure legend, the reader is referred to the web version of this article.)

dust source regions (Luo et al., 2003; Tanaka and Chiba, 2006; Yumimoto et al., 2009).

Dust fluxes reconstructed from dissolved thorium isotope concentrations in seawater from a number of INOPEX stations (Hayes et al., 2013) also correlate well with the sedimentary dust fluxes along the Southern and Kamchatka Transects (Fig. 9).
The good agreement between the core-top based reconstruction, the model simulation and the seawater-based reconstruction is a promising finding since the three techniques integrate over very different timescales, with the seawater approach integrating over 3-5 years versus centennial to millennial timescales covered by surface sediments, and because ${ }^{232}$ Th solubility carried by dust is not well constrained.

Previously published Holocene dust flux data from the SNP show a large range of $0.1-21.4 \mathrm{~g} / \mathrm{m}^{2} / \mathrm{yr}$ with no consistent geographical pattern. In contrast to the observations from the INOPEX samples, most direct aerosol collection station and sediment trap data compiled in DIRTMAP3 (Maher and Kohfeld, 2009, and references therein) fall either in the range of $0-1$ or $>3 \mathrm{~g} / \mathrm{m}^{2} / \mathrm{yr}$ and therefore are either lower or higher than our reconstructed fluxes. A potential reason for the discrepancy could be the relatively short time period covered by collection station and sediment trap studies (orders of months to years). Surface sediments integrate fluxes over centennial to millennial timescales and therefore integrate rare large dust events into average fluxes that are not captured by these studies. Sedimentary dust flux data compiled in DIRTMAP3 are generally higher than our reconstructions, possibly as a result of the inability to geochemically remove volcanic material. Dust fluxes based on dissolved aluminum concentrations in seawater in the North Pacific (Measures et al., 2005), with a limited spatial overlap with the INOPEX cruise track, appear to yield dust fluxes that are lower by about an order of magnitude than results presented here. The discrepancy may indicate uncertainties in the estimate of the $\mathrm{Al}$ residence time in this region (Hayes et al., 2013). Dust input estimates based on accumulation rates of quartz (Catubig et al., 1998; Kawahata et al., 2000) and ${ }^{232}$ Th (Kohfeld and Chase, 2011) tend to fall in the range of the INOPEX dust fluxes of $\sim 1-3 \mathrm{~g} / \mathrm{m}^{2} / \mathrm{yr}$.

\section{Summary and conclusions}

This study presents a core-top spatial survey of lithogenic input to the Subarctic North Pacific. We find contributions of eolian dust, IRD, volcanic ash, hemipelagic and riverine material to the lithogenic fraction of the sediments, requiring deconvolution of the different contributions to estimate the eolian dust flux. Grain size distributions and grain size data modeling indicate the presence of a component with an uniform fine grain size mode at $\sim 4 \mu \mathrm{m}$ over the entire SNP; however, grain size modeling alone does not allow us to deconvolve eolian dust from other fine lithogenic components, such as resuspended shelf sediments or volcanic ash (Fig. 6). This separation can be achieved by using the three independent geochemical proxies ${ }^{4} \mathrm{He}_{\text {terr, }}{ }^{232} \mathrm{Th}$ and REE (Figs. 3, 4). Our results indicate that eolian dust constitutes $80-100 \%$ of the lithogenic fraction in the sediments from the open ocean far away from volcanic arcs, and constitutes less than $50 \%$, with increased dilution of eolian dust by terrigenous input with volcanic signatures, along the margins (Fig. 5). Resulting dust fluxes show a highly consistent pattern among the three geochemical proxy approaches with highest input in the western SNP and constant fluxes of $1-2 \mathrm{~g} / \mathrm{m}^{2} / \mathrm{yr}$ over the remaining SNP (Fig. 8).

The consistency of the three independent geochemical tracers with each other, with previous dust flux data from the SNP based on sediment accumulation rates of quartz (Catubig et al., 1998; Kawahata et al., 2000) and ${ }^{232}$ Th (Kohfeld and Chase, 2011), as well as independent estimates from dissolved thorium isotope concentrations in seawater (Hayes et al., 2013) and modeling studies (Mahowald et al., 2005), indicates that all three are valuable proxies to reconstruct dust input in complex settings with multiple lithogenic components contributing to marine sediments. The combination of the geochemical proxies and grain size distributions from the same sediment samples shows that information on the 
size-fractionation of source material and the application of sizespecific source data are crucial for quantitative reconstructions of eolian dust input in marine sediments. Grain size distribution data alone can be misleading in the reconstruction of eolian dust input in near-coastal regions characterized by abundant fine-grained lithogenic contributions other than dust. Our approach provides an effective toolkit for dust flux studies in this HNLC region as well as other oceanic regions seeking to test the impact of dust on regional ecosystems and biogeochemical cycles (Duce and Tindale, 1991; Jickells et al., 2005; Martin, 1990). Our dust flux data will be helpful in the application of biogeochemical models to reconstruct nutrient cycling in the SNP in the present and past.

\section{Acknowledgements}

We would like to thank Roseanne Schwartz, Marty Fleisher, Louise Bolge, Linda Baker, Pat Malone and Nichole Anest for laboratory support at LDEO. We are thankful to Youbin Sun and Ryuji Tada for providing dust source samples. The paper was improved by constructive comments by Ryuji Tada, Lucia Korff, 2 anonymous reviewers and the editor, Gideon Henderson.

This work was supported by U.S. National Science Foundation grant OCE1060907 to G.W. and R.F.A. INOPEX samples were obtained during the SO202-INOPEX cruise in 2009 supported by the German Federal Ministry of Education and Research. Additional financial support comes from LDEO climate center grant 4-10780 to S.S., and the Jeanne \& Dan Valente Center for Arts and Sciences at Bentley University and the German Academic Exchange Service for B.M. The support of the German Science Foundation for S.S.'s Ph.D. work is acknowledged. This is LDEO contribution 7748.

\section{Appendix A. Supplementary material}

Supplementary material related to this article can be found online at http://dx.doi.org/10.1016/j.epsl.2013.11.008.

\section{References}

Bailey, J.C., 1993. Geochemical history of sediments in the northwestern Pacific Ocean. Geochem. J. 27, 71-90.

Biscaye, P.E., Grousset, F.E., Revel, M., Van der Gaast, S., Zielinski, G.A., Vaars, A., Kukla, G., 1997. Asian provenance of glacial dust (stage 2) in the Greenland Ice Sheet Project 2 Ice Core, Summit, Greenland. J. Geophys. Res., Oceans 102, 26765-26781.

Bishop, J.K.B., Davis, R.E., Sherman, J.T., 2002. Robotic observations of dust storm enhancement of carbon biomass in the North Pacific. Science 298, 817-821.

Boyd, P.W., Wong, C.S., Merrill, J., Whitney, F., Snow, J., Harrison, P.J., Gower, J., 1998. Atmospheric iron supply and enhanced vertical carbon flux in the NE subarctic Pacific: Is there a connection?. Glob. Biogeochem. Cycles 12, 429-441.

Cao, L.Q., Arculus, R.J., McKelvey, B.C., 1995a. Geochemistry and petrology of volcanic ashes recovered from Sites 881 through 884: A temporal record of Kamchatka and Kurile volcanism. In: Rea, D.K., Basov, I.A., Scholl, D.W., Allan, J.F. (Eds.), Proceedings of the Ocean Drilling Program. In: Sci. Res., vol. 145. Ocean Drilling Program, College Station, TX, pp. 345-381.

Cao, L.Q., Arculus, R.J., McKelvey, B.C., 1995b. Geochemistry of volcanic ashes recovered from Hole 887A. In: Rea, D.K., Basov, I.A., Scholl, D.W., Allan, J.F. (Eds.), Proceedings of the Ocean Drilling Program. In: Sci. Res., vol. 145. Ocean Drilling Program, College Station, TX, pp. 661-669.

Catubig, N.R., Archer, D.E., Francois, R., deMenocal, P., Howard, W., Yu, E.F., 1998. Global deep-sea burial rate of calcium carbonate during the last glacial maximum. Paleoceanography 13, 298-310.

Creamean, J.M., Suski, K.J., Rosenfeld, D., Cazorla, A., DeMott, P.J., Sullivan, R.C., White, A.B., Ralph, F.M., Minnis, P., Comstock, J.M., Tomlinson, J.M., Prather, K.A., 2013. Dust and biological aerosols from the Sahara and Asian influence precipitation in the Western U.S. Science 339, 1572-1578.

Crusius, J., Schroth, A.W., Gasso, S., Moy, C.M., Levy, R.C., Gatica, M., 2011. Glacial flour dust storms in the Gulf of Alaska: Hydrologic and meteorological controls and their importance as a source of bioavailable iron. Geophys. Res. Lett. 38, L06602. http://dx.doi.org/10.1029/2010GL046573.

Duce, R.A., Tindale, N.W., 1991. Atmospheric transport of iron and its deposition in the ocean. Limnol. Oceanogr. 36, 1715-1726.
Duce, R.A., Unni, C.K., Ray, B.J., Prospero, J.M., Merrill, J.T., 1980. Long-range atmospheric transport of soil dust from Asia to the Tropical North Pacific: temporal variability. Science 209, 1522-1524.

Falkowski, P.G., Barber, R.T., Smetacek, V., 1998. Biogeochemical controls and feedbacks on ocean primary production. Science 281, 200-206.

Ferrat, M., Weiss, D.J., Strekopytov, S., Dong, S.F., Chen, H.Y., Najorka, J., Sun, Y.B. Gupta, S., Tada, R., Sinha, R., 2011. Improved provenance tracing of Asian dust sources using rare earth elements and selected trace elements for palaeomonsoon studies on the eastern Tibetan Plateau. Geochim. Cosmochim. Acta 75, 6374-6399.

Gebhardt, H., Sarnthein, M., Grootes, P.M., Kiefer, T., Kuehn, H., Schmieder, F., Röhl, U., 2008. Paleonutrient and productivity records from the subarctic North Pacific for Pleistocene glacial terminations I to V. Paleoceanography 23, PA4212. http://dx.doi.org/10.1029/2007PA001513.

Gersonde, R., 2012. The expedition of the research vessel "Sonne" to the subpolar North Pacific and the Bering Sea in 2009 (SO202-INOPEX). Rep. Polar Mar Res. 643, 1-323.

Ginoux, P., Chin, M., Tegen, I., Prospero, J.M., Holben, B., Dubovik, O., Lin, S.J., 2001 Sources and distributions of dust aerosols simulated with the GOCART model. J. Geophys. Res., Atmos. 106, 20255-20273.

Gromet, L.P., Haskin, L.A., Korotev, R.L., Dymek, R.F., 1984. The "North American Shale composite": Its compilation, major and trace element characteristics. Geochim. Cosmochim. Acta 48, 2469-2482.

Harrison, S.P., Kohfeld, K.E., Roelandt, C., Claquin, T., 2001. The role of dust in climate changes today, at the last glacial maximum and in the future. Earth-Sci. Rev. 54 43-80.

Hayes, C.T., Anderson, R.F., Fleisher, M.Q., Serno, S., Winckler, G., Gersonde, R., 2013. Quantifying lithogenic inputs to the North Pacific Ocean using the long-lived thorium isotopes. Earth Planet. Sci. Lett. 383, 16-25.

Hsu, S.C., Huh, C.A., Lin, C.Y., Chen, W.N., Mahowald, N.M., Liu, S.C., Chou, C.C.K. Liang, M.C., Tsai, C.J., Lin, F.J., Chen, J.P., Huang, Y.T., 2012. Dust transport from non-East Asian sources to the North Pacific. Geophys. Res. Lett. 39, L12804 http://dx.doi.org/10.1029/2012GL051962.

Husar, R.B., Tratt, D.M., Schichtel, B.A., Falke, S.R., Li, F., Jaffe, D., Gasso, S., Gill, T., Laulainen, N.S., Lu, F., Reheis, M.C., Chun, Y., Westphal, D., Holben, B.N., Gueymard, C., McKendry, I., Kuring, N., Feldman, G.C., McClain, C., Frouin, R.J., Merrill, J., DuBois, D., Vignola, F., Murayama, T., Nickovic, S., Wilson, W.E., Sassen, K., Sugimoto, N., Malm, W.C., 2001. Asian dust events of April 1998. J. Geophys. Res., Atmos. 106, 18317-18330.

Jickells, T.D., An, Z.S., Andersen, K.K., Baker, A.R., Bergametti, G., Brooks, N., Cao, J.J., Boyd, P.W., Duce, R.A., Hunter, K.A., Kawahata, H., Kubilay, N., laRoche, J., Liss, P.S., Mahowald, N., Prospero, J.M., Ridgwell, A.J., Tegen, I., Torres, R., 2005. Global iron connections between desert dust, ocean biogeochemistry, and climate. Science 308, 67-71.

Jones, C.E., Halliday, A.N., Rea, D.K., Owen, R.M., 1994. Neodymium isotopic variations in North Pacific modern silicate sediment and the insignificance of detrital REE contributions to seawater. Earth Planet. Sci. Lett. 127, 55-66.

Jones, C.E., Halliday, A.N., Rea, D.K., Owen, R.M., 2000. Eolian inputs of lead to the North Pacific. Geochim. Cosmochim. Acta 64, 1405-1416.

Kaufman, Y.J., Tanré, D., Boucher, O., 2002. A satellite view of aerosols in the climate system. Nature 419, 215-223.

Kawahata, H., Okamoto, T., Matsumoto, E., Ujiie, H., 2000. Fluctuations of eolian flux and ocean productivity in the mid-latitude North Pacific during the last $200 \mathrm{kyr}$ Quat. Sci. Rev. 19, 1279-1292.

Keigwin, L.D., Jones, G.A., Froelich, P.N., 1992. A 15,000 year paleoenvironmental record from Meiji Seamount, far northwestern Pacific. Earth Planet. Sci. Lett. 111, 425-440.

Kohfeld, K.E., Chase, Z., 2011. Controls on deglacial changes in biogenic fluxes in the North Pacific Ocean. Quat. Sci. Rev. 30, 3350-3363.

Levin, Z., Ganor, E., Gladstein, V., 1996. The effects of desert particles coated with sulfate on rain formation in the Eastern Mediterranean. J. Appl. Meteorol. 35, 1511-1523.

Luo, C., Mahowald, N.M., del Corral, J., 2003. Sensitivity study of meteorological parameters on mineral aerosol mobilization, transport, and distribution. J. Geophys. Res., Atmos. 108, 4447. http://dx.doi.org/10.1029/2003JD003483.

Machalett, B., Oches, E.A., Frechen, M., Zller, L., Hambach, U., Mavkyanova, N.G., Markovic, S.B., Endlicher, W., 2008. Aeolian dust dynamics in central Asia during the Pleistocene: Driven by the long-term migration, seasonality, and permanency of the Asiatic polar front. Geochem. Geophys. Geosyst. 9, Q08Q09. http://dx.doi.org/10.1029/2007GC001938.

Maeda, N., Noriki, S., Narita, H., 2007. Grain size, La/Yb and Th/Sc of settling particles in the Western North Pacific: evidence for lateral transport of small Asian loess. J. Oceanogr. 63, 803-812.

Maher, B.A., Kohfeld, K., 2009. 'DIRTMAP' version 3, LGM and late holocene aeolian fluxes from ice cores, marine sediment traps, marine sediments and loess deposits. http://www.lec.lancs.ac.uk/dirtmap3.

Mahowald, N.M., Luo, C., 2003. A less dusty future?. Geophys. Res. Lett. 30, 1903. http://dx.doi.org/10.1029/2003GL017880.

Mahowald, N.M., Baker, A.R., Bergametti, G., Brooks, N., Duce, R.A., Jickells, T.D., Kubilay, N., Prospero, J.M., Tegen, I., 2005. Atmospheric global dust cycle and iron 
inputs to the ocean. Glob. Biogeochem. Cycles 19, GB4025. http://dx.doi.org 10.1029/2004GB002402.

Martin, J.H., 1990. Glacial-interglacial $\mathrm{CO}_{2}$ change: the iron hypothesis. Paleoceanography $5,1-13$.

Martin, J.H., Fitzwater, S.E., 1988. Iron deficiency limits phytoplankton growth in the north-east Pacific subarctic. Nature 331, 341-343.

Martin, J.H., Gordon, R.M., Fitzwater, S., Broenkow, W.W., 1989. VERTEX: phytoplankton/iron studies in the Gulf of Alaska. Deep-Sea Res. 36, 649-680.

McGee, D., 2009. Reconstructing and interpreting the dust record and probing the plumbing of Mono Lake. Ph.D. Thesis. Columbia University, New York, NY.

McGee, D., deMenocal, P.B., Winckler, G., Stuut, J.B., Bradtmiller, L.I., 2013. The magnitude, timing and abruptness of changes in North African dust deposition over the last 20,000 years. Earth Planet. Sci. Lett. 371, 163-176.

McKelvey, B.C., Chen, W., Arculus, R.J., 1995. Provenance of Pliocene-Pleistocene icerafted debris, Leg 145, Northern Pacific Ocean. In: Rea, D.K., Basov, I.A., Scholl, D.W., Allan, J.F. (Eds.), Proceedings of the Ocean Drilling Programm. In: Sci. Res. vol. 145. Ocean Drilling Program, College Station, TX, pp. 195-204.

Measures, C.I., Brown, M.T., Vink, S., 2005. Dust deposition to the surface waters of the western and central North Pacific inferred from surface water dissolved aluminum concentrations. Geochem. Geophys. Geosyst. 6, Q09M03. http://dx.doi.org/10.1029/2005GC000922.

Méheust, M., Fahl, K., Stein, R., 2013. Variability in modern sea surface temperature, sea ice and terrigenous input in the sub-polar North Pacific and Bering Sea: Reconstruction from biomarker data. Org. Geochem. 57, 54-64.

Moreno, T., Querol, X., Castillo, S., Alastuey, A., Cuevas, E., Herrmann, L., Mounkaila, M., Elvira, J., Gibbons, W., 2006. Geochemical variations in aeolian mineral particles from the Sahara-Sahel dust corridor. Chemosphere 65, 261-270.

Nagashima, K., Tada, R., Matsui, H., Irino, T., Tani, A., Toyoda, S., 2007. Orbital- an millennial-scale variations in Asian dust transport path to the Japan Sea. Palaeogeogr. Palaeoclimatol. Palaeoecol. 247, 144-161.

Nagashima, K., Tada, R., Tani, A., Sun, Y., Isozaki, Y., Toyoda, S., Hasegawa, H., 2011 Millennial-scale oscillations of the westerly jet path during the last glacial period. J. Asian Earth Sci. 40, 1214-1220.

Nakai, S., Halliday, A.N., Rea, D.K., 1993. Provenance of dust in the Pacific Ocean. Earth Planet. Sci. Lett. 119, 143-157.

Natland, J.H., 1993. Volcanic ash and pumice at Shatsky Rise: Sources, mechanisms of transport, and bearing on atmospheric circulation. In: Natland, J.H., Storms, M.A., et al. (Eds.), Proceedings of the Ocean Drilling Program. In: Sci. Res., vol. 132. Ocean Drilling Program, College Station, TX, pp. 57-66.

Olivarez, A.M., Owen, R.M., Rea, D.K., 1991. Geochemistry of eolian dust in Pacific pelagic sediments: Implications for paleoclimatic interpretations. Geochim. Cosmochim. Acta 55, 2147-2158.

Opdyke, N.D., Foster, J.H., 1970. Paleomagnetism of cores from the North Pacific. In: Hays, J.D. (Ed.), Geological Investigations of the North Pacific. Geological Society of America, Boulder, CO, pp. 83-119.

Otosaka, S., Honda, M.C., Noriki, S., 2004. La/Yb and Th/Sc in settling particles: Vertical and horizontal transport of lithogenic material in the western North Pacific. Geochem. J. 38, 515-525.

Patterson, D.B., Farley, K.A., Norman, M.D., 1999. ${ }^{4}$ He as a tracer of continental dust: A 1.9 million year record of aeolian flux to the west equatorial Pacific Ocean. Geochim. Cosmochim. Acta 63, 615-625.

Rea, D.K., 1994. The paleoclimatic record provided by eolian deposition in the deep sea: the geologic history of wind. Rev. Geophys. 32, 159-195.

Rea, D.K., Hovan, S.A., 1995. Grain size distribution and depositional processes of the mineral component of abyssal sediments: Lessons from the North Pacific. Paleoceanography 10, 251-258.

Rea, D.K., Janecek, T.R., 1981. Mass-accumulation rates of the non-authigenic inorganic crystalline (eolian) component of deep-sea sediments from the western mid-Pacific mountains. Deep Sea Driling Project Site 463. In: Thiede, J., et al (Eds.), Deep Sea Drilling Project. In: Initial Reports, vol. 62. U.S. Government Printing Office, Washington, DC, pp. 653-659.

Rea, D.K., Leinen, M., 1988. Asian aridity and the zonal westerlies: Late Pleistocene and Holocene record of eolian deposition in the northwest Pacific Ocean. Palaeogeogr. Palaeoclimatol. Palaeoecol. 66, 1-8.
Ruddiman, W.F., Glover, L.K., 1972. Vertical mixing of ice-rafted volcanic ash in North Atlantic sediments. GSA Bull. 83, 2817-2836.

Schlitzer, R., 2011. Ocean Data View Version 4.3.10. Alfred Wegener Institute for Polar and Marine Research, Bremerhaven, Germany.

Scholl, D.W., Hein, J.R., Marlow, M., Buffington, E.C., 1977. Meiji sediment tongue: North Pacific evidence for limited movement between Pacific and North American plates. Geol. Soc. Am. Bull. 88, 1567-1576.

Shigemitsu, M., Narita, H., Watanabe, Y.W., Harada, N., Tsunogai, S., 2007. Ba, Si, U, $\mathrm{Al}, \mathrm{Sc}, \mathrm{La}, \mathrm{Th}, \mathrm{C}$ and ${ }^{13} \mathrm{C} /{ }^{12} \mathrm{C}$ in a sediment core in the western subarctic Pacific as proxies of past biological production. Mar. Chem. 106, 442-455.

St. John, K.E.K., Krissek, L.A., 1999. Regional patterns of Pleistocene ice-rafted debris flux in the North Pacific. Paleoceanography 14, 653-662.

Sun, J.M., Zhang, M.Y., Liu, T.S., 2001. Spatial and temporal characteristics of dust storms in China and its surrounding regions, 1960-1999: Relations to source area and climate. J. Geophys. Res., Atmos. 106, 10325-10333.

Svensson, A., Biscaye, P.E., Grousset, F.E., 2000. Characterization of late glacial continental dust in the Greenland Ice Core Project ice core. J. Geophys. Res., Atmos. 105, 4637-4656.

Tanaka, T.Y., Chiba, M., 2006. A numerical study of the contributions of dust source regions to the global dust budget. Glob. Planet. Change 52, 88-104.

Taylor, S.R., McLennan, S.M., 1985. The Continental Crust: Its Composition and Evolution. Blackwell Scientific Publications, Palo Alto, CA.

Tegen, I., Fung, I., 1994. Modeling of mineral dust in the atmosphere: Sources, transport, and optical thickness. J. Geophys. Res., Atmos. 99, 22897-22914.

Tegen, I., Werner, M., Harrison, S.P., Kohfeld, K.E., 2004. Relative importance of climate and land use in determining present and future global soil dust emission. Geophys. Res. Lett. 31, L05105. http://dx.doi.org/10.1029/2003GL019216.

Tsoar, H., Pye, K., 1987. Dust transport and the question of desert loess formation. Sedimentology 34, 139-153.

Uematsu, M., Wang, Z.F. Uno, I. 2003. Atmospheric input of mineral dust to the western North Pacific region based on direct measurements and a regional chemical transport model. Geophys. Res. Lett. 30, 1342. http://dx.doi.org/ 10.1029/2002GL016645.

Uno, I., Eguchi, K., Yumimoto, K., Liu, Z., Hara, Y., Sugimoto, N., Shimizu, A., Takemura, T., 2011. Large Asian dust layers continuously reached North America in April 2010. Atmos. Chem. Phys. 11, 7333-7341.

van de Flierdt, T., Frank, M., Halliday, A.N., Hein, J.R., Hattendorf, B., Günther, D., Kubik, P.W., 2003. Lead isotopes in North Pacific deep water - implications for past changes in input sources and circulation patterns. Earth Planet. Sci. Lett. 209, 149-164.

VanLaningham, S., Pisias, N.G., Duncan, R.A., Clift, P.D., 2009. Glacial-interglacial sediment transport to the Meiji Drift, northwest Pacific Ocean: Evidence for timing of Beringian outwashing. Earth Planet. Sci. Lett. 277, 64-72.

Weber, E.T., Owen, R.M., Dickens, G.R., Halliday, A.N., Jones, C.E., Rea, D.K., 1996. Quantitative resolution of eolian continental crustal material and volcanic detritus in North Pacific surface sediment. Paleoceanography 11, 115-127.

Weber, E.T., Owen, R.M., Dickens, G.R., Rea, D.K., 1998. Causes and implications of the middle rare earth element depletion in the eolian component of North $\mathrm{Pa}$ cific sediment. Geochim. Cosmochim. Acta 62, 1735-1744.

Winckler, G., Anderson, R.F., Schlosser, P., 2005. Equatorial Pacific productivity and dust flux during the mid-Pleistocene climate transition. Paleoceanography 20, PA4025. http://dx.doi.org/10.1029/2005PA001177.

Winckler, G., Anderson, R.F., Fleisher, M.Q., McGee, D., Mahowald, N., 2008. Covariant glacial-interglacial dust fluxes in the equatorial Pacific and Antarctica. Science 320, 93-96.

Yumimoto, K., Eguchi, K., Uno, I., Takemura, T., Liu, Z., Shimizu, A., Sugimoto, N., 2009. An elevated large-scale dust veil from the Taklimakan Desert: Intercontinental transport and three-dimensional structure as captured by CALIPSO and regional and global models. Atmos. Chem. Phys. 9, 8545-8558.

Zdanowicz, C., Hall, G., Vaive, J., Amelin, Y., Percival, J., Girard, I., Biscaye, P., Bory, A., 2006. Asian dustfall in the St. Elias Mountains, Yukon, Canada. Geochim. Cosmochim. Acta 70, 3493-3507.

Zhao, T.L., Gong, S.L., Zhang, X.Y., Blanchet, J.P., McKendry, I.G., Zhou, Z.J., 2006. A simulated climatology of Asian dust aerosol and its trans-Pacific transport. Part I: Mean climate and validation. J. Climate 19, 88-103. 